\title{
Placing a Well-Designed Vegan Diet for Slovenes
}

\author{
Boštjan Jakše (D)
}

check for updates

Citation: Jakše, B. Placing a Well-Designed Vegan Diet for Slovenes. Nutrients 2021, 13, 4545. https: / / doi.org/10.3390/ nu13124545

Academic Editors: Leonie-Helen Bogl, Klazine Van der Horst and Karin Haas

Received: 1 December 2021 Accepted: 17 December 2021 Published: 18 December 2021

Publisher's Note: MDPI stays neutral with regard to jurisdictional claims in published maps and institutional affiliations.

Copyright: (C) 2021 by the author. Licensee MDPI, Basel, Switzerland. This article is an open access article distributed under the terms and conditions of the Creative Commons Attribution (CC BY) license (https:/ / creativecommons.org/licenses/by/ $4.0 /)$.
Department of Food Science, Biotechnical Faculty, University of Ljubljana, SI-1000 Ljubljana, Slovenia; bj7899@student.uni-lj.si

\begin{abstract}
Interest in vegan diets has increased globally as well as in Slovenia. The quantity of new scientific data requires a thorough synthesis of new findings and considerations about the current reserved position of the vegan diet in Slovenia. There is frequently confusion about the benefits of vegetarian diets that are often uncritically passed on to vegan diets and vice versa. This narrative review aims to serve as a framework for a well-designed vegan diet. We present advice on how to maximize the benefits and minimize the risks associated with the vegan diet and lifestyle. We highlight the proper terminology, present the health effects of a vegan diet and emphasize the nutrients of concern. In addition, we provide guidance for implementing a well-designed vegan diet in daily life. We conducted a PubMed search, up to November 2021, for studies on key nutrients (proteins, vitamin $\mathrm{B}_{12}$, vitamin $\mathrm{D}$, omega-3 long chain polyunsaturated fatty acids (eicosapentaenoic acid (EPA) and docosahexaenoic acid (DHA)), calcium, iron, zinc, iodine and selenium) in vegan diets. Given the limited amount of scientific evidence, we focus primarily on the general adult population. A well-designed vegan diet that includes a wide variety of plant foods and supplementation of vitamin $B_{12}$, vitamin D in the winter months and potentially EPA/DHA is safe and nutritionally adequate. It has the potential to maintain and/or to improve health. For physically active adult populations, athletes or individuals with fast-paced lifestyles, there is room for further appropriate supplementation of a conventional vegan diet according to individuals' health status, needs and goals without compromising their health. A healthy vegan lifestyle, as included in government guidelines for a healthy lifestyle, includes regular physical activity, avoidance of smoking, restriction of alcohol and appropriate sleep hygiene.
\end{abstract}

Keywords: vegan diet; plant-based; health; sport; environment; barriers; education; coronavirus

\section{Introduction}

Contemporary dietary guidelines need to focus on health, the environment and animal welfare; however, they are currently threatening all three [1,2]. Dietary and lifestyle changes towards a healthy and sustainable diet/lifestyle could be associated with reductions in premature mortality from diet/lifestyle-related noncommunicable diseases, reductions in environmental impacts, COVID-19 severity and management and preventing the next coronavirus pandemic [3-7]. According to the United Nations, The American Public Health Association and several experts in the time of the COVID-19 pandemic, we should focus on dealing with the root causes of this epidemic spread, which include farming methods that crowd huge numbers of animals into small spaces [2,8].

There is increasing interest in eating vegan diets [9]. In a survey from 2018 across 28 countries, $3 \%$ of the global adult population was identified as vegan (e.g., researchers tested 20,313 adults, of which 575 were vegans) [10]. Currently, the worldwide prevalence of vegetarianism (which also includes people on a vegan diet) is not uniform [11]. In addition, generally, income is a significant driver for the type of diet people choose to follow (i.e., higher incomes are associated with diets rich in animal proteins rather than carbohydratebased staples) [10]. Importantly, in the above-mentioned international survey, $20 \%$ of vegans have followed the diet only for about a year [10]. Regardless, different motives can lead to the adoption of a vegan diet. According to several studies, common motives for 
choosing a vegan diet include ethical and health-related benefits, body mass management, environmental concerns and religious reasons [12-18]. With that in mind, this has led to the development of new vegan products for the consumer market, including meat alternatives, other vegan alternatives [17] and plant-based protein supplements [19,20].

A study that used Google Trends to explore global popularity (the number of searches on vegan-related terms as a fraction of total searches in a given country, of various search categories) showed that the popularity of veganism was at an all-time high in 2020. Vegan-related queries were most popular in the United Kingdom, Australia, Israel, New Zealand and Austria, while Slovenia was in 15th place [21]. During the last six decades, the vegan diet has been rigorously investigated. During this time, 1440 articles were published by 4586 researchers. The leading country was the United States ( 471 articles), while the most prolific institutions were the University of Oxford (Oxford, UK; 59 articles) and Loma Linda University (Loma Linda, CA, United States, 38 articles) [22]. Existing data support the position that a shift towards a well-designed vegan diet is beneficial for sustainable food systems, planetary health and the prevention of common noncommunicable diseases [1]. However, although various professional associations have recognized a well-designed vegan diet as beneficial and healthy for people at all stages of life [23-29], others have expressed concerns about an inadequacy in terms of a lack of certain nutrients and its consequences [30,31].

Although there is ample evidence of the health benefits of a well-designed vegan diet, vegans in Slovenia are frequently faced with prejudice on unsubstantiated grounds [30,32-37]. Discussions about vegan diets are often emotionally charged, which is also due to a lack of education and professional knowledge or because of conflicts of interest and ignorance of the results of research on a vegan diet. Furthermore, there is considerable debate about a vegan diet and lifestyle, especially concerning nutritional deficiencies, health benefits, motives for adopting vegan diet and the difficulties in implementing a well-designed vegan diet (i.e., concerns that it is complicated, expensive and appropriate only for highly motivated individuals) and healthy lifestyle into everyday life.

Our narrative review of the literature summarizes the evidence on topics related to a well-designed vegan diet (Figure 1): (1) The definition of a vegan diet; (2) Health effects of a vegan diet; (3) Environmental footprint of a vegan diet; (4) Nutrients of concern in a vegan diet; (5) Practical recommendations for implementing a vegan diet; (6) Barriers to the implementation of a vegan diet. Importantly, this review of scientific literature is not meant to be a "recipe book" and does not provide sufficient detail for the immediate implementation of a well-designed vegan diet for a particular individual. Moreover, our aim is to analyse existing studies to incorporate information on individual topics that contributes to solid conclusions. We adopt this approach to the reviewing literature not because of the possible failure of support for a vegan diet using classic methodology but to provide to the Slovenian audience a comprehensive view of the current positioning of the vegan diet. It may serve as a springboard to establish appropriate planning that suits individuals' dietary needs, health status, goals and personal circumstances. 


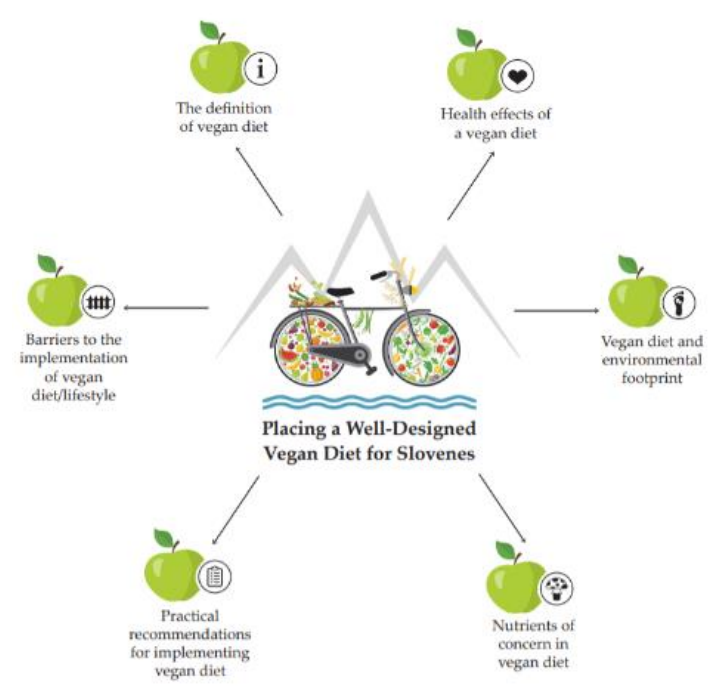

Figure 1. Placing a Well-Designed Vegan Diet for Slovenes.

\section{The Definition of a Vegan Diet}

The vegan diet (e.g., in terms of nutrition, not ideology) excludes all animal-based foods (i.e., meat, fish, dairy and eggs) but includes a wide variety of plant-based food groups (i.e., fruits, vegetables, grains, legumes, nuts and seeds, spices and herbs, mushrooms and algae) $[38,39]$. However, it does not require the consumption of whole foods or the restriction of fat or refined sugar [40]. Notably, in this review we maintain a distance from other subclassifications of vegan diets, namely, the raw vegan diet, the frugivorous diet and the macrobiotics diet [11].

For a vegan diet to provide documented health benefits, it must be well-designed weekly and daily from a variety of plant-based food groups that are eaten often enough, meals prepared with healthy methods of preparation (i.e., boiling, steaming, baking on baking paper) and eaten meals that induce satiety [41].

Importantly, there are many different definitions of a vegan (plant-based) diet, which makes comparisons among existing vegan diets and with other dietary patterns difficult. Consequently, this may cause significant confusion among researchers and the public [42].

In general, when referring to a vegan lifestyle, all the structures of recommendations for a healthy and active lifestyle for the general population should be considered, such as regular and appropriate physical activity (PA), nonsmoking, limited alcohol consumption, avoidance of prolonged sitting and appropriate sleep hygiene [43-45].

\section{Health Effects of a Vegan Diet}

\subsection{In Adults}

\subsubsection{Body Mass and Body Composition}

In the modern world, weight and obesity are among the main global public health challenges [46-48]. More than fifty obesity-related diseases exist, which further increases the global burden of obesity [49]. Obesity is defined as the accumulation of excess body fat and not simply excess body mass; this is very important for individuals who are within the normal body mass index (BMI) class (e.g., those with so-called sarcopenic obesity) [50,51]. Sarcopenic obesity is currently a significant public health problem with increasing prevalence worldwide (e.g., up to $42 \%$ of adults) [52,53].

The most recent data in a Slovenian report (e.g., national cross-sectional food survey, SI. Menu, that collected food consumption data in the period from March 2017 to April 2018 [54]) showed that $22 \%$ of adolescents, $39 \%$ of adults and $43 \%$ of older adults were overweight, and a similar proportion was observed in the obese class $(6 \%$ of adolescents, $20 \%$ of adults and $32 \%$ of older adults). These numbers are in line with the assessed average body fat percentage (BF \%) (measured by bioimpedance) for adult and older females (33\% and $37 \%)$ as well as for adult and older males (25\% and $29 \%$ ) [55]. 
Vegan diets have been explored with various study designs (i.e., randomized/nonrandomized (un)controlled, crossover, cross-sectional, a meta-analysis of intervention/observational studies and narrative review) and have shown reduced body mass [56-67] and improved body composition status [59,60,67-73]. For example, a 12-week randomized controlled trial ("the Broad study") showed substantial body mass loss results in overweight or obese patients with type 2 diabetes or some form of cardiovascular disease within 3 months $(-8.6 \mathrm{~kg}), 6$ months $(-12.1 \mathrm{~kg})$, and 12 months $(-11.5 \mathrm{~kg})$ of follow-up without mandating regular PA or restricting total energy intake [56]. Furthermore, our intervention study of a community-based whole-food plant-based lifestyle program (i.e., a supplemented vegan diet, 45 min of moderate-intensity PA 2-3 times weekly, and a support system) also showed substantial body mass loss with effective muscle mass preservation $[59,68]$. Regular and appropriate PA is extremely important, as body fat loss and muscle mass preservation are crucial for improvements in body mass and body composition $[51,74,75]$, better visual body image [76,77] and appetite control [78-80]. Physical activity, as an important lifestyle component and one of the key factors for body mass management, has been found to have an extremely beneficial effect on various aspects of health [81,82]; however, appropriate body mass/body composition is more effectively addressed by combining both dietary changes and PA $[51,83,84]$.

Therefore, a vegan lifestyle in terms of effective and healthy body mass loss or successful control of proper body mass and body composition includes a well-designed vegan diet combined with a healthy and active lifestyle. This means including at least 150-300 min/week of vigorous-intensity PA (e.g., resistance workouts) or some equivalent combination of moderate-intensity and vigorous-intensity aerobic PA as recommended by the World Health Organization (WHO) guidelines for healthy adults. Furthermore, the WHO also recommends that an individual add two or more times a week a moderateintensity to high-intensity resistance workout [85].

\subsubsection{Cardiovascular Health}

Currently, cardiovascular diseases (CVDs) remain the leading global cause of death, accounting for as many as one-third of all deaths [86]. In 2016, almost 50\% of CVD deaths in the European Region were a consequence of inadequate diet, characterized by a low intake of whole grains, nuts, seeds, fruits and omega-3 fatty acids but a high intake of sodium [87]. The most important risk factors are dyslipidaemia, arterial hypertension and diabetes type 2 [88,89]. In addition to an unhealthy diet, the most common environmental factors influencing the development of cardiovascular disease are smoking, excessive alcohol intake and lack of PA $[89,90]$. Therefore, due to its efficacy, safety and affordability, dietary change has been recognized as the first-line intervention to prevent elevated cholesterol levels and CVD (deaths) [87,91,92].

In the most comprehensive study in Slovenia in terms of CVD prevention, researchers tested 500,000 adults (25\% of all Slovenians). The results were alarming: elevated cholesterol levels were found in $69 \%$ of examined adult individuals [93]. Furthermore, according to data from the National Institute of Public Health of Slovenia, almost $50 \%$ of adults had elevated blood pressure [94]. Moreover, the results of an epidemiological study on the prevalence of elevated blood pressure in Slovenia between 2007-2009 (e.g., researchers tested 3422 adults of the 15,000 invited) found elevated blood pressure in $64 \%$ of examined adult individuals [95].

Many study designs have shown that a vegan diet successfully reduces common CVD risk factors or is associated with beneficial short- and long-term health effects (i.e., lowdensity lipoprotein cholesterol, triglycerides, blood pressure) $[56,60,61,65,67,68,71,96-107]$. A meta-analysis of 31 observational studies comparing the effect of a vegan diet with an omnivorous diet on CVD risk factors showed that vegans' average LDL cholesterol values were $2.36 \mathrm{mmol} / \mathrm{L}$, their triglycerides were $1.1 \mathrm{mmol} / \mathrm{L}$ and their blood pressure was 118/77 $\mathrm{mmHg}$ [63]. Similarly favourable findings were shown in a systematic review and meta-analysis of 30 observational and 19 clinical trials comparing the effect of a vegetarian 
diet (i.e., vegan diet included) with an omnivorous diet on plasma lipids. Consumption of vegetarian diets, particularly a vegan diet, was associated with lower levels of plasma lipids [108].

In many cases, a well-designed vegan diet can stop or even reverse the progression of CVD endpoints [99-102]. Researchers performed randomized controlled trials with longterm follow-up ("the Lifestyle Heart Trial") on 48 patients with moderate to severe coronary heart disease [99]. The interventional program consisted of a low-fat (10\%) "vegetarian" diet (with $12.4 \mathrm{mg} /$ day of dietary cholesterol; practically a "vegan" diet), cessation of smoking, stress management training and moderate exercise. After 1 year, $82 \%$ of patients in the experimental group showed a significant change towards the regression of severe coronary atherosclerosis without the use of lipid-lowering drugs [109]. After 5 years, an even greater regression of coronary atherosclerosis measured by percent diameter stenosis was found [99]. In another study of 198 patients (177 adherent to a low-fat vegan diet, 21 nonadherent) with multiple comorbidities (i.e., hyperlipidaemia, hypertension, angina, myocardial infarction, diabetes), a $0.6 \%$ recurrent event rate of major cardiac events was observed after an average of 3.7 years of follow-up. Improvements were confirmed with positron emission tomography (PET scan) on myocardial reperfusion and angiographic evidence of disease reversal [100].

Given the available data, a well-designed vegan diet with some modifications in diet and PA and mandatory supervision by a CVD specialist who is also an expert on the vegan diet may be a viable option for individuals who are interested in vegan diets. This might be especially true given that CVDs are the leading global cause of mortality and that no other diet has shown such a profound beneficial effect. Although increasingly favourable scientific data exist regarding the beneficial effects of a vegan diet and CVD health, further well-designed studies are warranted.

\subsubsection{Diabetes Type 2}

The worldwide prevalence of diabetes type 2 is rapidly increasing. It was estimated that in 2019, 463 million individuals had diabetes type 2 . The projection suggests that by 2045 , this number will reach as many as 700 million patients with diabetes type 2 [110]. Furthermore, the prevalence of diabetes (type 1 and type 2) in Slovenia is defined by data on prescribed blood glucose-lowering drugs, and the 2017 report has shown that approximately 111,400 individuals take medicines to lower blood glucose $(8 \%$ of the population), which is a $33 \%$ increase compared to 2008 [111]. Moreover, according to data from the National Institute of Public Health of Slovenia, the total number of patients with diabetes was estimated to be 137,000 , while the number of identified and undiagnosed patients was estimated to be as high as 211,000 [112].

In a recent review of the literature, researchers support the feasibility of diabetes type 2 remission in diabetic patients using lifestyle as the primary means of treatment, whereas PA appears to have a minor role compared to the dietary regimen; however, it may significantly improve insulin resistance and beta-cell activity [113]. In addition, it has been demonstrated that with regard to diabetes type 2 outcomes, a well-designed vegan diet in short- and long-term settings has the greatest success compared to a controlled diet and other dietary interventions [67,114-118]. A vegan diet $(n=49)$ and a conventional "diabetes-type-diet" ( $n=50)$ in the treatment of type 2 diabetes were tested in a long-term (74-week) randomized controlled trial, which showed that the vegan diet significantly improved diabetes type 2 status (i.e., glycaemia and plasma lipid concentration, body mass reduction) [114]. Importantly, a vegan diet addresses core pathophysiologic mechanisms, insulin resistance and diminished beta-cell function. For example, beta-cell function and fasting insulin sensitivity improvement using a vegan diet were recently investigated in a 16-week randomized controlled trial on 75 overweight adults $(n=38$ on a vegan diet, $n=37$ on a control diet). Researchers have demonstrated that beta-cell function and fasting insulin sensitivity, both core pathophysiologic mechanisms of diabetes type 2 , could be significantly improved [118]. Possible mechanisms for improvement of beta-cell function 
and insulin sensitivity that are suggested include reduced visceral and subfascial fat in muscle tissue or changed fat distribution (by well-designed (i.e., high in carbohydrates) vegan diet and exercise), improved incretin secretion, reduced lipotoxicity, glucotoxicity, oxidative stress and inflammation [118].

Since diabetes type 2 is a lifestyle disease, the overall data suggest that a well-designed vegan diet and lifestyle changes should be the first-line treatment for newly diagnosed patients with diabetes type 2, and may be an extremely powerful adjunctive method in patients with a long history of diabetes type 2 [113,119-121]. Importantly, adherence to a low-fat vegan diet/lifestyle to manage diabetes was comparable to and often higher than adherence to a conventional diet/lifestyle in several studies [122].

\subsubsection{Other Health Benefits}

Since the available financial support is not sufficient to thoroughly investigate a vegan diet, it is worth mentioning that the literature confirms other health benefits of vegan diets. Some are of greater scientific value (i.e., liver and kidney health, favourable changes in gut microbiota, prostate cancer, women's menstrual, menopausal and postmenopausal health, short-term mood state, migraine severity and frequency) [67,72,123-128]; however, some have limited scientific value (i.e., case studies about chronic kidney disease, diabetes type 1 /insulin-dependent diabetes mellitus, low-grade follicular lymphoma, lupus nephritis and less common dementia in a large-scale observational Adventist Health study [129-136]). Notably, these findings are sufficiently impressive to warrant further examination of these results in well-designed studies.

For example, in a 16-week randomized control trial, an intervention group $(n=122)$ followed a low-fat vegan diet, and in a subset of participants $(n=44)$, hepatocellular and intramyocellular lipids were quantified by proton magnetic resonance spectroscopy. The hepatocellular and intramyocellular lipid levels decreased by $34 \%$ and $10 \%$, respectively, while none of these variables significantly changed in the control group with no dietary changes [67]. In line with these results, a recent prospective study on 26 patients affected by nonalcoholic fatty liver disease (NAFLD) who adhered to a vegan diet for six months showed improved liver enzymes (e.g., ALT, AST and GGT values), and normalization of liver function tests as a whole was observed in $77 \%$ of patients [131]. Furthermore, in a 1-year randomized controlled trial on a group of 93 patients with early-stage prostate cancer (PSA: 4-10 ng/mL and cancer Gleason scores less than 7), 44 were supplemented (e.g., with soy protein, selected vitamins and minerals, nutrient-fortified plant-based foods, eicosapentaenoic acid (EPA, C20:5n-3) and docosahexaenoic acid (DHA, C22:6n-3) from fish oil supplementation) with a low-fat vegan diet/lifestyle (including moderate-intensity aerobic activity, stress management and group support). Researchers found remarkably decreased serum PSA values (4 of the baseline average) and inhibited LNCaP (lymph node carcinoma of the prostate) cell growth by 70\% [124]. To further clarify the association between vegetarian and vegan diets and the risk for various chronic diseases and mortality from cancer, researchers conducted a meta-analysis of observational studies (86 crosssectional and 10 cohort prospective) and found that a vegan diet conferred a significantly reduced risk $(-15 \%)$ of the incidence of all cancers [38].

As these are different health issues, the recommendation refers only to the fact that a healthy diet, which is undoubtedly a well-designed vegan diet (e.g., which can be customized and/or supplemented), may offer beneficial health support to individuals facing various health challenges. Accordingly, the cooperativeness of an individual patient with a specialist physician is extremely important; however, we suggest in this regard a specialist who knows the results of the research on vegan diets well enough and, even better, who knows how to properly supervise the patient on a well-designed vegan diet.

\subsubsection{Sport and Exercise Performance}

Gladiators and philosophers in ancient times were aware that strict vegetarian (vegan) diets are compatible with physical and intellectual performances $[137,138]$. Currently, 
there is still a common belief in the general population that a vegan diet may be detrimental to endurance and muscle strength. Clinical and cross-sectional studies comparing vegan, lacto-ovo-vegetarian and omnivorous diets have shown comparable [18,139-142] or better [143] aerobic capacity, anaerobic performance or muscle strength on a vegan diet $[18,139-143]$. A recent narrative review of observational and interventional studies of young and competitive athletes on vegan diets showed that they are able to tolerate and sustain higher physical burdens for longer durations and to recover from physical stress more rapidly. This supports the assumption that a well-designed vegan diet is compatible with peak performance sports [137] and is associated with a good health status [137,144].

Physically active individuals and athletes on a vegan diet have often added a variety of dietary supplements to their basic diet. The prevailing speculation is that plant-protein supplements are inferior to animal-based protein supplements in building muscle and increasing strength. However, vegan protein supplements (soy in a meta-analysis of nine long-term studies ( $\geq 6$ weeks), and mycoprotein, a single-cell fungal protein, in a shortterm study (3 days)), compared to animal protein supplements, offer equivalent support for muscle mass gain and strength in healthy older adults and in untrained participants engaged in resistance exercise $[145,146]$. In support of this contention are the results of a recent meta-analysis showing that soy protein supplementation in men undergoing resistance exercise training led to gains in muscle mass and strength similar to those observed in men supplemented with whey protein or other animal proteins [146]. In addition, a 6-week case study in a world-class vegan male professional powerlifter reported body composition changes [147]. The results suggested that a vegan diet supplemented with vitamins $B_{12}$ and $D, E P A / D H A$, creatine and vegan protein combined with a resistance workout may support the loss of body mass and $\mathrm{BF} \%$ but preserve and even increase muscle mass [147]. Furthermore, for physically active people and athletes, there is room for further appropriate supplementation of a conventional vegan diet according to individuals' health status, needs and goals without compromising their health (e.g., until proven otherwise), through the use of plant-based protein supplements or meal replacements, sport drinks and creatine [16,140,148,149].

Importantly, we are aware that many famous and successful vegan athletes exist among us [137,150]; unfortunately, to our knowledge, we have no solid scientific data on their actual diet, lifestyle and health status. This provides an important incentive for researchers to obtain more data through scientific methods. In addition, research on the long-term effects of a vegan diet on sport performance or exercise benefits is still very limited; therefore, the current, albeit encouraging, evidence should be interpreted with caution.

\subsection{During Pregnancy, Breastfeeding, Infancy and Childhood}

Over the last twenty years, many professional associations in the field of nutrition and pediatrics have published their position statements/guidelines on the suitability of a vegan diet during pregnancy, breastfeeding, infancy and childhood [151,152]. The majority of them stand on the position that a well-designed vegan diet is healthy and appropriate for these particularly sensitive periods [151]. However, all of them clearly emphasize that a vegan diet requires more careful planning and appropriate supplementation [151,152]. Furthermore, the position of the European Society for Paediatric Gastroenterology, Hepatology, and Nutrition (ESPGHAN) is that a well-designed vegan diet can support children's normal growth and development but should be used under appropriate medical or dietetic supervision [153]. Moreover, when breastfeeding is not possible in the case of a dairy-free diet in the first year of life, the North American Society for Pediatric Gastroenterology, Hepatology, and Nutrition (NASPGHAN) highlights that properly formulated vegan formulas (e.g., soy or rice-based formulas) can be an alternative to cow's milk-based formulas [154].

Nutrition during the perinatal period and early development has an important impact on health into adulthood (i.e., adult body mass, common chronic diseases, food preferences) $[153,155,156]$. The suitability of a vegan diet can be assessed through nutritional 
adequacy and the incidence of pediatric diseases as well as chronic morbidity later in life (e.g., CVD, cancer). Therefore, during these delicate stages, it is extremely important to offer (i) appropriate guidance on a well-designed vegan diet and (ii) medical supervision for nutrients of concern. Special consideration is required to obtain the recommended amounts of the following nutrients on a vegan diet: vitamin $B_{12}$ and D, EPA/DHA and iodine. With well-designed planning, the adequacy of energy intake and other nutrients (i.e., protein, calcium, iron, zinc and selenium) can be achieved. Twenty years ago, a narrative review established that a well-designed vegan diet can be adequate for children at all ages [157]. However, we do not have many studies of quality due to difficulties in recruiting parents of vegan children because parents fear criticism from the medical profession [158].

In two recent publications, a narrative review and a prospective paper, the researchers established evidence that a well-designed vegan diet during pregnancy and lactation is nutritionally complete, safe and healthy for both the mother and offspring, emphasizing that it should follow all the criteria that define it as adequate $[159,160]$, with some adjustments compared to the guidelines for the normal adult population. Although more evidence is needed, based on the current wide range of research results on this topic, we can conclude that a well-designed vegan diet has a protective effect against poor pregnancy outcomes (e.g., obesity, preeclampsia and various pediatric diseases) and preterm delivery, and can support lactation $[159,160]$. Awareness must be raised about complete dietary intake, especially for nutrients of concern and necessary dietary supplements, according to international guidelines $[153,159,160]$.

Similarly, a well-designed vegan diet is suitable for subsequent periods of life [23,151,159]. To express an objective position on the appropriateness of feeding children a vegan diet, and given the shortcomings of high-quality studies on this stage of the lifecycle, it is necessary to examine this topic from a broader perspective [161]. In brief, childhood obesity has become a major global epidemic related to substantial social and health burdens worldwide [162], which would not be the case if a well-designed vegan diet or any other form of recognized balanced diets were followed (e.g., vegetarian, omnivore).

Furthermore, four recent cross-sectional studies investigated the nutritional adequacy of infants/children who followed a nonvegan and vegan diet [163-166]. In the United States, research was conducted on 9848 children (aged 1-6 years) whose parents and caregivers completed $24 \mathrm{~h}$ dietary recall interviews. The results of the children who followed a "normal" diet might be seen as concerning. In nearly all of the children $(99 \%)$, fiber deficiency was detected, $87 \%$ were deficient in vitamin $\mathrm{D}, 69 \%$ in vitamin E, $58 \%$ in potassium and $17 \%$ in calcium. Furthermore, the average consumption of DHA was well below the European Food Safety Authority (EFSA) recommendation (e.g., $70-100 \mathrm{mg} /$ day) in nearly all children (97-99\%), while $99.8 \%$ of the children exceeded the recommended sodium intake [164]. In Germany, the energy and macronutrient intake and the anthropometrics of 430 children (127 vegetarians, 139 vegans and 164 omnivores) aged $1-3$ years was examined. As no significant difference in dietary intake and anthropometrics between the study groups was found, the authors concluded that a vegan diet in early childhood is capable of providing the same amount of energy and macronutrients and therefore enables normal growth. The results of the study also revealed that the children on a vegan diet consumed 2 times and 2.3 times less added sugar than children on a vegetarian diet and an omnivorous diet and $22 \%$ and $46 \%$ more fiber, respectively [163]. In Finland, a small cross-sectional study of 40 children (10 vegetarians, 6 vegans and 24 omnivores) with an average age of 3.5 years was conducted to determine their micronutrient status. The study found that fat intake was similar and that the intake of saturated fatty acids and cholesterol were significantly lower, whereas the intake of monounsaturated fatty acids, linoleic acid (LA, C18:2, n-6) and alpha linoleic acid (ALA, C18:3, n-3) were higher among children who followed a vegan diet than among those who consumed an omnivore diet. In addition, when comparing the nutrients of concern, children on a vegan diet compared with children on an omnivore diet consumed $93 \%$ more fiber, $277 \%$ more folate, $61 \%$ more 
iron and 14\% more zinc (all without supplementation), and a similar intake of vitamin D (without supplementation) and iodine (with supplementation, e.g., iodized salt), but no EPA/DHA intake (without supplementation) [165]. Finally, the most recent cross-sectional study on 187 Polish children (63 vegetarian, 52 vegan and 72 omnivores) aged 5-10 years revealed an increased risk for $\mathrm{B}_{12}$ deficiencies in children who followed a vegan diet but not in those who were supplemented with vitamin $B_{12}$ and vitamin $D$. In addition, the prevalence of possible $B_{12}$ deficiency was $16 \%, 19 \%$ and $40 \%$ in omnivores, vegetarians and vegans, respectively. However, moderate and mild iron deficiency anemia was found among vegans and vegetarians in $2 \%$ (in both) and $6 \%$ and $7 \%$ of the sample (no case on omnivores) without severe iron deficiency anemia. Moreover, the prevalence of depleted iron stores was $13 \%$ in omnivores, $18 \%$ in vegetarians and $30 \%$ in vegans [166]. Given that vegan and vegetarian children in this study were recruited via advertising (i.e., web sites and social media that were targeting issues concerned with vegetarianism and veganism), their diets were presumably not optimally supervised by a nutrition expert. In this way, they could be given guidance on a well-designed vegan diet for their age group, beyond the advice on supplementation. Moreover, this information is of the utmost importance since the above-mentioned Finnish study showed that children on a vegan diet had an intake of $61 \%$ more iron compared with children on an omnivorous diet, while both groups of children had comparable iron stores $(16 \mu \mathrm{g} / \mathrm{L}$ vs. $14 \mu \mathrm{g} / \mathrm{L})$ [165].

It is well accepted that predispositions for CVD appear in childhood [167-169] and in pregnant women who are overweight or obese and/or have high blood pressure $[170,171]$. In Cleveland, a 4-week prospective randomized trial was performed on 30 pairs of obese children with hypercholesterolemia (aged 9-18 years) and their parents. They were randomized into two groups, one following a vegan diet without added fat and the other following the American Heart Association (AHA) diet. Both groups received $2 \mathrm{~h}$ weekly classes on nutritional education. While both diets demonstrated beneficial effects, in the vegan diet group, the beneficial changes were over 2 times more evident with regard to body mass/fat, systolic blood pressure, total and LDL cholesterol, high-sensitivity C-reactive protein, insulin and waist circumference [172]. These findings are in line with the abovementioned cross-sectional study results for 187 Polish vegan children, in which a vegan diet was associated with a healthier CVD risk profile but with relative differences in growth (e.g., $3 \mathrm{~cm}$ shorter and 4-6\% lower bone mineral content) and specific nutritional status compared to an omnivorous diet [166]. Notably, concerns about the inadequacy of some nutrients in a vegan diet, especially in early life, are of great importance. However, society faces greater challenges related to the consequences of an obesogenic food environment that fuels current major public health epidemics (e.g., obesity, type 2 diabetes and common chronic disease) with a food-addictive dietary pattern consisting of an excess of energy, highly processed carbohydrates, free sugar, saturated and total fat and cholesterol $[173,174]$.

During the metabolic programming period, maternal nutritional behavior represents the crucial component for favourable health outcomes. We need more high-quality evidence involving the prenatal, pregnancy, infancy and childhood periods (for which the main challenge is ethics and adherence). To date, however, we have sufficient overall evidence that a well-designed vegan diet (e.g., with an adequate intake of nutrients) that is properly medically supervised should be considered safe and healthy for pregnancy, infancy and childhood $[23,25,153,160,175,176]$. In contrast, an unbalanced vegan diet that lacks energy and micronutrients should not be seen as protective in this sensitive window for nutritional programming and metabolic imprinting in terms of later beneficial outcomes $[156,177]$.

\section{Vegan Diet and Environmental Footprint}

The EAT-Lancet Commission convened 37 leading scientists from 16 countries in various disciplines and stated that food is the single strongest lever to optimize human health and environmental sustainability on Earth. Thus, the recommendation of the commission was to increase the consumption of plant-based foods (i.e., fruits, vegetables, nuts, seeds and whole grains) while substantially limiting animal-based foods [1]. Similarly, 
11,258 scientists from 153 countries encouraged the eating of mostly plant-based foods while reducing the global consumption of animal-based products to improve individual health and to significantly lower emissions of greenhouse gases (GHGs), including methane [178].

At least one-third of global anthropogenic GHG emissions are attributed to the current food system (e.g., as it exists now), whereas the largest contribution comes from agriculture and land use/land-change activities (71\%) [179]. In a recent systematic review that examined the changes in GHG emissions as well as land and water use as a result of shifting current dietary intakes to environmentally more sustainable dietary patterns, it was shown that a vegan diet has the greatest impact on the reduction in GHG emissions [180]. In addition, German study examined the external climate cost using life-cycle assessment and meta-analytical approaches and showed that organic plant-based products were associated with the lowest external GHG emission cost [181].

In conclusion, a systematic review of 16 studies and 18 reviews that address the important question of which diet has the least environmental impact suggests that for the environment, a vegan diet may be the optimal diet [182].

\section{Nutrients of Concern in Vegan Diet}

There are several nutrients of particular concern in a vegan diet. Importantly, we are aware that few of these concerns are legitimate, while others are disputable when we talk about a well-designed vegan diet in which the majority of calories come from whole-food, plant-based foods.

A recent systematic review on the dietary intake of European vegans revealed several nutrient deficiency concerns [183]. The review included 48 studies (12 cohorts and 36 cross-sectional), of which 6 cohorts and 16 cross-sectional studies were published 15 or more years ago. Although every review may be of great importance, in this case, several nutrients of concern may be irrelevant today, as we have increasingly accessible research results on the well-designed vegan diet and books, lectures, podcasts and free guides that are more accessible to the general population.

The recommended values for dietary intake in Slovenia are based on Central European D-A-CH (German [D], Austrian [A], and Swiss [CH] reference) values, while recommendations for the intake of EPA/DHA are taken from the European Food and Safety Authority (EFSA) [184-186]. Concerns about the nutritional adequacy of vegan diet intake may be divided into three groups:

- $\quad$ sufficient intake of energy and protein;

- nutrients that should be obtained from dietary supplements or enriched foods (i.e., vitamin B12, vitamin D, omega-3 fatty acids); and

- micronutrients of concern (i.e., calcium, iron, zinc, iodine and selenium).

\subsection{Energy and Protein Intake Concerns}

People on a vegan diet must take into consideration that an unprocessed or minimally processed vegan diet may be low(er) in energy if it is not well-designed. In several interventional studies, successfully using a vegan diet for CVD risk factors or diabetes type 2 management for obese and overweight patients might involve potential concerns about a lower average energy intake $(1315,1422$ and $1450 \mathrm{kcal} /$ day) $[60,114,118]$, which can result in certain micronutrient inadequacies (additional to the nutrients that must be obtained via supplementation). Furthermore, in two of the three recently published studies mentioned, the authors did not report micronutrient intake values (i.e., they studied other outcomes) $[60,118]$, whereas in earlier long-term interventional studies (74 weeks), the authors published detailed dietary intake reports, which confirmed nutrient inadequacy for calcium intake but not for iron and zinc intake [114] based on valid dietary guidelines for healthy people on an omnivorous diet. Other researchers have analysed the dietary intake of a well-designed, very low-fat, supplemented vegan diet (e.g., with soy protein, selected vitamins and minerals, nutrient-fortified plant-based foods and EPA/DHA from fish oil supplementation) that was successfully used in the "treatment" of early-stage 
prostate cancer. For this group of patients (PA was included), the researchers reported higher energy (2125 kcal/day) and protein intake (108 g/day or $20 \%$ of energy) and the consequent nutritional adequacy of micronutrients of concern (i.e., calcium, iron and zinc) [187]. Furthermore, in the last decade, in numerous cross-sectional studies on participants who ate vegan diets, authors reported higher energy intake (i.e., from 1791 to $2832 \mathrm{kcal} /$ day) $[98,143,188-195]$, which is in line with recommendations for including moderate-intensity PA levels as part of healthy and active lifestyles [184,196]. Notably, higher energy intake per se does not automatically result in nutritional adequacy of nutrients of concern (i.e., a higher energy intake might be easier to achieve by eating an ultra-processed vegan diet that is deficient in fiber and micronutrient content, for example, with excessive usage of vegetable oils, refined grains, fruit juice or margarine, which are generally very nutrient-depleted foods). In conclusion, based on the results of nutritional adequacy in intervention studies and (comparative) cross-sectional studies, we take the position that a well-designed vegan diet is easily energy adequate. However, proper meal composition and intake to satiety (ad libitum) is extremely important and may be different from Western-type eating in obesogenic food environments [73,174,197].

A recent review reported that average protein and amino acid intake from vegan diets ranged from $62 \mathrm{~g} /$ day to $82 \mathrm{~g} /$ day [198], which is in line with reference values for protein intake for the general adult population and for elderly individuals set to $0.8 \mathrm{~g}$ and $1.0 \mathrm{~g}$ per $\mathrm{kg}$ body mass/day (48-57 g/day and 57-67 g/day) [184,196]. In brief, vegan diets typically meet or even exceed reference values for protein intake, especially when energy intake is adequate and based on whole-food sources [98,143,187,188,190,191,193-195,199]. These data are not surprising, since plant-based protein sources are readily available in protein-rich food groups, such as legumes, (intact) whole grains, nuts and seeds (butters) as whole-food sources, and in plant-protein supplements and plant-based meal replacements. Regardless, there is a prejudice that plant-based protein sources are not of the same quality as animal sources. Several new review studies explain that restricting the intake certain amino acids (i.e., methionine, tryptophan and leucine) and overall protein intake, which was once considered a limitation of a vegan diet, is recognized as beneficial, as it generally decreases ageing-related comorbidities and thereby increases health and life-span [200,201]. Furthermore, there is also a prejudice that plant-based protein sources do not enable maximum muscle synthesis as animal-based proteins do and that this can only be achieved through protein supplementation; however, these arguments are not supported by the facts. The required sufficient total protein intake (approximately $1.6 \mathrm{~g}$ per $\mathrm{kg}$ body mass/day) and protein intake per meal for maximum muscle synthesis is between $20-25 \mathrm{~g}$, thus providing at least 1.2-3 g of leucine [202], which is fairly easy to achieve if there is a need; for example, a meal with $60 \mathrm{~g}$ of lentils and $60 \mathrm{~g}$ of buckwheat porridge exceeds $20 \mathrm{~g}$ of protein, while a meal with $100 \mathrm{~g}$ of whole grain spaghetti, $50 \mathrm{~g}$ of soy flakes $/ 70 \mathrm{~g}$ of soy tofu and $100 \mathrm{~g}$ of corn contains approximately $25 \mathrm{~g}$ of protein [203]). In addition, sufficient intake of the amino acid leucin has been proposed as a key factor to trigger the muscle growth response. However, most plant-based protein sources are similarly rich in leucine (i.e., average ranging from 6-12 g/100 g) compared to animal protein sources (i.e., average ranging from 8-12 g/100 g) [198]. This often-advocated belief is based on a system of determining the "Digestible Indispensable Amino Acid Score" (DIAAS), where animalbased proteins (e.g., meat and milk) exhibited greater DIAAS values in the reference for adults than plant-based proteins, with the exception of potatoes and soy protein $[142,204]$.

We emphasize that this remains a controversial method of assessing the quality of plant- and animal-protein sources. Even with the DIAAS method, this process maintains several limitations that are specifically related to plant-based dietary patterns. These include failure to translate nitrogen differences into protein-conversion factors between plant- and animal-based foods; limited representation of commonly consumed plant-based foods in larger quantities (e.g., fruits, vegetables, certain legumes, nuts and seeds), thus contributing to underestimation of the actual digestibility of plant sources of protein in humans eating strict plant diets within the DIAAS framework; inadequate recognition of increased 
digestibility associated with frequently consumed heat-treated and processed foods; formulation centered on fast-growing animal models rather than humans; and a focus on individual isolated ingredients compared to the vegan nutritional matrix. All of these factors reduce its application both at rest and in an exercise setting [205].

Regardless, the protein quality of a single ingredient should be of less importance than the quality of the well-designed mixed (vegan) meal that is normally consumed [20,204,205]. Various strategies may be applied to increase the anabolic properties of plant-based protein if there is a justified need, including (i) consuming higher amounts of and/or multiple plantbased protein-rich sources at a meal or (ii) using plant-based protein supplements [19,20]. With regard to the latter, the results of well-designed studies demonstrated limited eligibility for the consumption of protein supplements for muscle growth or strength when performing resistance training if protein intake from a conventional diet has already met the recommendations [206,207]. Notably, not all adults, physically active people or even most competitive athletes want or need to achieve maximum muscle synthesis for sport performance. Muscle mass and strength are primarily built by resistance training [208]. Therefore, to achieve the recommended protein intake, a vegan diet needs to be well-designed, which includes the appropriate composition of a meal plan and a sufficient amount eaten. Last, it must be emphasized that on a well-designed vegan diet, there is no need to "consciously" combine different plant-protein sources in each meal on a given day $[198,209]$. However, even if it happens that a particular vegan meal is not optimally composed, the individual has a supply of free amino acid "pools" in body tissues (e.g., mostly in skeletal muscle and body fluids) in the amount of approximately 70-90 $\mathrm{g}[210,211]$.

Some amino acids, such as taurine, carnosine, creatine and anserine, are almost exclusively found in foods of animal origin [212]. Thus, some authors conclude that since these nutrients are absent from all plants (e.g., grains, legumes, potatoes and nuts) [213], vegans are at great risk of deficiencies, particularly if they are physically active or if they regularly perform intensive exercise [148]. Currently, however, health and sport-performance efficacy and safety have been well established only for creatine [214,215]. In addition, vegan athletes may benefit even more than omnivores (e.g., improved exercise performance); however, at present, the research is inconclusive on whether an increased creatine capacity translates to a greater increase in performance in vegan athletes than among their omnivore peers [149]. Furthermore, $\beta$-alanine supplementation has been shown to increase muscle carnosine concentrations, leading to improvements in high-intensity exercise performance $[148,212]$. However, research is clearly lacking on, for example, $\beta$-alanine and taurine in physically active or competitive vegan athletes $[148,216]$. Moreover, taurine is an essential amino acid for preterm neonates that is provided by breast milk [217] and is a potential ergogenic aid for preventing muscle damage, attenuating muscle protein catabolism, decreasing oxidative stress and improving performance in endurance athletes [148,212]. Further research is needed to validate the health and performance role of these other amino acids (e.g., need, efficacy and safety) for the general adult vegan population and in physically active or competitive vegan athletes.

\subsection{Nutrients That Should Be Obtained from Dietary Supplements or Enriched Foods \\ 5.2.1. Vitamin $B_{12}$}

Vitamin $B_{12}$ deficiency is a common global nutritional problem in people of all ages, especially among elderly individuals [218-220]. Furthermore, adequate intake of vitamin $B_{12}$ is seen as the greatest concern in vegan diets. As vitamin $B_{12}$ is not synthesized by plants or by (vegan) animals, it needs to be supplemented regularly with reliable sources [23]. For adults (16-65 years), the reference value is set to $4 \mu \mathrm{g} /$ day $[184,186]$. However, because of substantial differences in its absorption rate, which depends on intake, age, BMI, health status and oral dosage (e.g., preferable in the form of cyanocobalamin [221], except in impaired renal function [222]), 100-200 $\mu \mathrm{g}$ of $\mathrm{B}_{12} /$ day or 2000-4000 $\mu \mathrm{g} \mathrm{B} \mathrm{B}_{12} / w$, divided into 2-4 doses/week, is recommended. A high intake recommendation compared to the reference value takes into account the efficiency of absorption and passive absorption 
routes [222-224]. Finally, routine laboratory testing (i.e., at least serum vitamin $B_{12}$ status and, if possible, methylmalonic acid (MMA) and total plasma homocysteine status, which are considered better markers of vitamin $B_{12}$ deficiency than serum vitamin $B_{12}$ ), is warranted to detect a possible vitamin $B_{12}$ deficiency [223].

\subsubsection{Vitamin D}

Vitamin D deficiency is another major nutritional public health issue worldwide and is common among people of all ages. This might be the case even in countries with low latitudes, where it has been generally assumed that because of an abundance of UVB radiation, vitamin D synthesis is sufficient [225]. However, it seems that vitamin D deficiency is primarily a consequence of today's institutional lifestyle. Furthermore, due to the high incidence of vitamin D deficiency in the autumn-winter period ( $80 \%$ of adult and healthy Slovenes have vitamin D (25-hydroxycytamin D) insufficiency, and $40 \%$ have severe vitamin D deficiency, with an average vitamin D intake of only $3 \mu \mathrm{g} /$ day (for adults, the reference value is set to $20 \mu \mathrm{g} /$ day) [226,227]).

It is generally accepted that the primary vitamin D sources are sunlight (with a sufficient UVB index), diet and dietary supplements [228]. It is practically impossible to meet recommendations for vitamin D $(20 \mu \mathrm{g} /$ day $)$ exclusively by preformed foods (i.e., fish liver oil, oily fish, liver and, in smaller doses, meat and egg yolk). According to Slovenian data (e.g., Open Platform for Clinical Nutrition, the online application tool with an extensive food/dish database), to provide enough vitamin D exclusively through diet, an individual should regularly consume large amounts of wild salmon (i.e., $17 \mu \mathrm{g}$ vitamin D/150 g), egg yolks (i.e., $1 \mu \mathrm{g}$ vitamin $\mathrm{D} / 100 \mathrm{~g})$, whole-fat milk $(<1 \mu \mathrm{g}$ vitamin $\mathrm{D} / 7 \mathrm{dcl})$ and chicken liver $(1 \mu \mathrm{g}$ vitamin D/100 g) [203]. Furthermore, vitamin D-rich foods normally contain high amounts of saturated fat, cholesterol and possibly various environmental contaminants [41,229].

The status of vitamin $\mathrm{D}$ was found to be lower among vegans than omnivores when serum vitamin D (i.e., 25-hydroxyvitamin D) levels were examined among vegans living at high geographical latitudes or in winter or early spring months $[23,230]$. However, based on data from cross-sectional studies comparing the dietary intake of vitamin $\mathrm{D}$ intake among vegans or omnivores $[189,226,231]$ and the current serum vitamin D status of adults and healthy Slovenes [227] or high-performance-level Slovenian athletes [232], we may conclude that the problem of vitamin D deficiency does not originate in dietary patterns. Furthermore, researchers in Adventist Health Study 2 examined vitamin D intake relative to serum vitamin $\mathrm{D}$ status and could not confirm a significant difference in serum vitamin D levels between vegetarians (e.g., those who ate meat and/or fish $<1$ time/month) and nonvegetarians [233].

To conclude, in addition to safe, sufficient and regular exposure to sunlight in the spring and summer months (with a sufficiently high UBV index), adequate and regular vitamin D supplementation regardless of diet pattern is recommended in the autumn and winter months (October-April) with 800-2000 IU/day (for pregnant women with 1500-2000 IU/day) [234]. Moreover, for people with suboptimal vitamin D status or older or obese individuals, vitamin D intake should be increased under the supervision of a personal physician $[235,236]$.

\subsubsection{Omega-3 Fatty Acids}

To ensure sufficient intake of omega-3 fatty acids, a well-designed vegan diet should include proper amounts of ALA and EPA/DHA. ALA is synthesized by plants, while EPA/DHA is synthesized by phytoplankton. Plant-based foods are particularly good sources of ALA (e.g., flaxseeds, chia and hemp seeds, rapeseed oil, walnuts and soy). Furthermore, ALA may endogenously be converted to EPA/DHA; however, the conversion rate is slow and inefficient and affected by FADS1 and FADS2 polymorphisms, intake of omega-6 fatty acids, lifestyle and health status characteristics (i.e., diet, age, sex, smoking, alcohol and chronic diseases) [237-241]. 
Due to great genetic variability, differences in lifestyle and health status, advancing age and pregnancy and lactation requirements, supplementation with EPA/DHA may be warranted. Direct intake of EPA/DHA can be ensured by eating fish or supplements (i.e., from fish oils or other marine sources and cultured from microalgae) [240,242]. Compared to omnivores, vegans typically have lower serum and plasma levels of EPA/DHA [190,237,243], which may be due to different intakes of ALA, EPA/DHA and to the numerous factors discussed above. However, the EPIC-Norfolk study results showed that vegans had comparable plasma levels of EPA/DHA to omnivores, regardless of the fact that they did not additionally take in EPA/DHA [239].

It is suggested to consume at least one tablespoon per day of flaxseed or chia seeds to obtain an adequate intake of ALA [237,244]. In addition, given the inconclusive evidence, for vegans with reduced conversion ability, for vegans who have greater need and to maintain long-term cognitive health, $250 \mathrm{mg}$ /day pollution-free EPA/DHA (i.e., microalgae, fish oil and other marine sources, yeast) should be supplemented in addition to an adequate intake of ALA [185,237,245,246]. Furthermore, for pregnant and lactating mothers who do not eat fish or other marine sources, experts recommend $300 \mathrm{mg} / \mathrm{d}$ DHA [242].

\subsection{Micronutrients of Concern (i.e., Calcium, Iron, Zinc, Iodine and Selenium)}

\subsubsection{Calcium}

For adults (of both sexes) in Slovenia, an adequate intake of calcium is set to $1000 \mathrm{mg} /$ day $[184,186]$. According to the results of recent European cross-sectional studies, this quantity can be easily met with a well-designed vegan diet or is comparable to intake on an omnivorous diet [71,98,190,191,199]; however, other studies disagree [188,189,192,193,195,231,247]. Notably, omnivore groups in these studies also did not reach the calcium intake recommendation $[192,194,231,248]$.

In many respects, this variability suggests that adequate calcium intake is a general problem of proper meal planning rather than a problem of a vegan diet per se. Although still speculative, the evidence of calcium intake among vegan diets is in line with the results of global dietary calcium intake among general adults [249]. Due to known paradoxical results of observational studies where high calcium intake was found to be associated with a high prevalence of hip fracture, and due to the serious limitations of most interventional studies (i.e., short duration, high habitual calcium intake, the method used), the reference for adults to maintain appropriate bone health is set differently by the World Health Organization (500 mg/day), the United Kingdom (700 mg/day) and the United States (1000 mg/day) [250].

Interestingly, the results of a recent German cross-sectional study that compared the bone health of adult vegans $(n=36)$ and omnivores $(n=36)$ found a $5 \%$ difference in one measurement of bone health status. However, this small study should not be considered clinically relevant to the drawing of solid conclusions since the results of quantitative ultrasound measures were not adjusted for BMI and the sub-analysis showed a trend of bone health improvement with the duration of a vegan diet [251]. Our speculative interpretation is in line with the results of the current review, which also suggests that there is no evidence that a proper vegan diet, when carefully designed to maintain adequate calcium and vitamin D intake, has detrimental effects on bone health and, in fact, may have beneficial effects [252]. The importance of a well-designed vegan diet was further suggested by findings in a recent Epic Oxford study on UK vegans. In this study, it was found that the fracture rates among vegans were higher than those among omnivores even after controlling for BMI, calcium intake and bone mineral density [253]. This concern was probably due to a combination of low calcium intake $(611 \mathrm{mg} /$ day and $580 \mathrm{mg} /$ day for men and women), low vitamin D status (e.g., high geographical latitude "condition" supplementation [230]) and, perhaps, vitamin $B_{12}$ inadequacy and very low PA levels. In addition, the UK vegan diet was poorly designed because fiber intake was below $30 \mathrm{~g} /$ day, whereas fat intake was close to $30 \%$ of total energy intake; therefore, these results should not be a reference source for well-designed vegan diets [253]. 
Unfortunately, serious conclusions on the basis of a recent systematic review with a meta-analysis of 17 cross-sectional studies, where researchers examined the association between vegetarian diets (including a vegan diet) and an omnivorous diet on bone health, are not possible. The reasons for this are that only five studies on a vegan diet were included in the review, of which one study included raw vegans, another included Buddhist nuns and one older adult (aged 70-89 years), where the protein intake of the subjects on a vegan diet was only $35 \mathrm{~g} /$ day, while two performed comparable bone mineral density to the subjects on the omnivore diet [254]. Finally, with regard to the association between calcium and bone health, resistance training might have much more importance [255].

Furthermore, the problem of calcium absorption from plant food sources is often mentioned due to the higher content of oxalates (and phytic acid in legumes, cereals and nuts/seeds, for example) in some sources (e.g., spinach) but not in other sources (e.g., broccoli, kale or kiwi), where calcium absorption from broccoli is comparable to milk (41\% from broccoli vs. 32\% from milk) [256-258]. Regardless, according to the abovementioned results of recent European cross-sectional studies that did not estimate an adequate calcium intake among adult vegans [188,189,192,193,195,231,247], it seems to be often a great challenge to consume enough calcium-rich plant foods every day (in comparison, drinking two to three cups of cow's milk seems much easier). Importantly, in addition to a sufficient total intake of calcium from any plant food source, we also paid attention to the regular intake of a sufficient amount of dark leafy greens and/or cruciferous vegetables and fruits.

In conclusion, a well-designed vegan diet that includes sufficient and regular consumption of plant-based foods with a high calcium content (e.g., cruciferous and green leafy vegetables with spinach as an outlier for the high oxalate content, legumes and seeds, especially tempeh and calcium-set tofu, as an outlier for the phytate content, and dried figs), regardless of the absorption rate, while avoiding excess salt intake, may provide adequate calcium intake.

\subsubsection{Iron and Zinc}

Several of the frequently mentioned micronutrient intakes of concern (i.e., iron and zinc inadequacy) in a vegan diet have also been highlighted in past review studies. In contrast, cross-sectional research published in the US and European countries in the last 15 years did not confirm the aforementioned insufficient intake of iron (i.e., adequate intake for females and males is 10-15 mg/day and $10 \mathrm{mg} /$ day [196]) and zinc (i.e., adequate intake for females and males is 7-10 mg/day and 11-16 mg/day, depending on phytate intake [196]) $[143,188,189,191,193,195,231,247]$.

It is widely known that plant-based iron (i.e., nonheme iron) is not absorbed as efficiently as heme iron from animal-based foods. However, avoidance or restriction of the intake of heme iron is considered beneficial (e.g., more carefully controlled to avoid overload) [259-262]. Nevertheless, nonheme iron absorption from plant-based foods can be significantly enhanced (even over 300\%) by adding vitamin C-rich foods to the meal (e.g., fruits, bell pepper, broccoli, vinegar) [263]. In addition, adding garlic and onion to grains or legumes may significantly increase the bioaccessibility of iron by up to $66 \%$ in grains and up to $73 \%$ in legumes in both their raw and cooked forms [264]. It is also important that the consumption of herbal teas (i.e., black and green), coffee, cocoa or red wines is at least one hour apart from a meal [262,265].

In a number of cross-sectional studies over the last 10 years, researchers also found that zinc intake among vegans was adequate; in addition, vegans performed much better than omnivores in regard to zinc intake [143,188,189,191,193,195,231]. Nevertheless, a well-designed, high-fiber vegan diet (e.g., a diet with high intake of whole grains, legumes, fruits and vegetables) may require a higher zinc intake due to high phytate content and/or a high calcium intake that partially inhibits its absorption [196,266]. Similar to iron, adding both garlic and onion to grains or legumes may significantly increase the bioaccessibility of zinc by up to $159 \%$ in grains and up to $50 \%$ in legumes in both their raw and cooked 
forms [264]. In addition, zinc-containing plant foods (e.g., legumes, grains, nuts and seeds) can be further increased by appropriate methods of preparation (e.g., soaking, germination or fermentation) of certain plant food groups [267].

\subsubsection{Iodine and Selenium}

Worldwide, iodine deficiency disorder is considered to be a major nutritional challenge that manifests as a health problem that affects all groups of people [268]. Nevertheless, vegans appear to have an increased risk of low iodine status [247,269]; therefore, a welldesigned vegan diet should properly address this challenge.

The reference value for adequate iodine intake for adults is $150 \mu \mathrm{g} /$ day $[184,186]$, which cannot be easily achieved without exceeding the permitted reference for daily salt intake $[270,271]$. According to the most recent estimates on iodine status, published in 2012 , the proportion of the Slovenian population with an iodine level lower than $100 \mu \mathrm{g} / \mathrm{L}$ was $23 \%$ [272,273]. These data are of great importance, since excessive sodium intake (e.g., $40 \%$ of salt is sodium) is a leading dietary risk factor associated with elevated blood pressure, CVD and premature death [274]. Moreover, up to $80 \%$ of dietary salt is usually consumed with processed foods [275], especially baked goods, cheeses and processed meats [276]. Because a well-designed vegan diet does not contain these food groups, it may include added iodized salt within food preparation (e.g., in salads, vegan burgers, pastas, potatoes, risotto, soups and sauce), used with caution if various high-salt additives are included in food preparation (e.g., soy or tamari sauce) or pre-prepared meals (e.g., salted canned legumes or salted nuts). Importantly, we must take into account that during boiling $(37 \%)$, pressure cooking $(22 \%)$, steaming $(20 \%)$ and roasting $(6 \%)$, iodine losses occur [277], so it is reasonable to adjust cooking methods to minimize iodine losses (i.e., seasoning with salt at the end of preparation). In addition, seaweed (e.g., nori, awake, kelp), a naturally representative-rich source of iodine, is not consumed very often in Slovenia. Nevertheless, in the case of a regular intake of seaweed (e.g., particularly kombu), excessive intake of iodine should be considered (there is an urgent need to improve the database on the nutrient content of iodine in various foods and products). In addition, plant-based food sources usually contain small amounts of iodine (e.g., potatoes with peels, berries and legumes), so their consumption in greater amounts is encouraged. However, current recommendations for salt fortification are suggested to be revised [270], or appropriate iodine supplementation might be suggested.

For adults (of both sexes) in Slovenia, adequate intake of selenium for females and males is set to $60 \mu \mathrm{g} /$ day and $70 \mu \mathrm{g} /$ day [196]. According to the results of recent European cross-sectional studies, this quantity can be easily met with a well-designed vegan diet or is comparable to selenium intake on an omnivore diet [71,190,231,247]; however, other studies disagree $[195,248]$. Importantly, several cross-sectional studies evaluating the dietary intake of vegans did not report selenium intake $[188,189,191,192,199]$, which suggests that there is an urgent need to improve the database on the nutrient content of selenium in various foods and products. Regardless, plant-based sources rich in selenium are whole grains, legumes, vegetables, nuts and seeds [39,278]. In addition, one Brazil nut a day, a naturally representative rich source of selenium, is an ideal way of meeting selenium recommendations $[39,278]$.

\section{Practical Recommendations for Implementing Vegan Diet}

A well-designed vegan diet is suitable in general for normally active adults. It should provide sufficient energy and nutrient intake, which can be achieved with appropriate weekly and daily meal planning using primarily nutrient-dense, unprocessed or minimally processed plant-based foods.

Based on official Slovenian and different European recommendations for generally healthy adults $[184-186,279,280]$ and the (review) studies on a vegan diet $[23,24,56,58,60,67,71,73,100,104,114,124,137,140,148,199,281]$, we suggest the main points of a well-designed vegan diet for healthy adults. It should be characterized by a high intake 
of fiber ( $\geq 45-60 \mathrm{~g} /$ day), a moderate intake of protein ( $<15 \%$ of energy), and a low intake of total fat (10-20\% of energy), saturated fat ( $\leq 5 \%$ of energy), free sugars ( $<5 \%$ of energy) and sodium (1500 $\mathrm{mg} /$ day). The required supplementation must include reliable sources of vitamin $B_{12}$ for the whole year and vitamin $D$ in the winter months (vitamin fortified foods and/or a supplement), and optionally may include EPA/DHA throughout the year. Therefore, we recommend a well-designed vegan diet for generally healthy adults:

- unprocessed or minimally processed plant-based foods, especially whole grains, legumes, fruits and vegetables, can be eaten ad libitum (i.e., moderate to full satiety) [197];

- $\quad$ whole grains (e.g., oats, buckwheat, rice, millet, quinoa, corn, rye), legumes (e.g., beans, lentils, soy foods, peas, chickpeas) and fruits (e.g., all types but preferably berries) should provide the majority of energy intake and should be included in most meals [41];

- tubers (e.g., white and sweet potatoes), colorful, green leafy and cruciferous vegetables, fresh/dry herbs, spices and aromatics are encouraged on a daily basis [41];

- nuts (e.g., walnuts, hazelnuts, almonds, peanuts) and seeds (e.g., flaxseeds, chia, sesame and hemp seeds) should be consumed daily but sparingly within a meal and in a natural form (without added salt or oil and, if possible, unroasted) [282];

- plant-based or non-dairy milk alternatives (with vitamin $\mathrm{D}, \mathrm{B}_{12}$ and calcium when possible): (a) cereal based: oat milk, rice milk, corn milk, spelt milk; (b) legume based: soy milk, peanut milk, lupin milk, cowpea milk; (c) nut based: almond milk, coconut milk, hazelnut milk, pistachio milk, walnut milk; (d) seed based: sesame milk, flax milk, hemp milk, sunflower milk; and (e) pseudo-cereal based: quinoa milk, teff milk and amaranth milk are optional and, whenever possible, should have no free sugars, added vegetable oil or salt [283,284];

- to enhance the aroma and flavor as well as the antioxidative potential of dishes, culturally inspired spice combinations are recommended: fresh and/or dried herbs, spices and aromatics, such as Mediterranean, which is comprised of basil, garlic, leek, marjoram, onion, oregano, rosemary, sage, thyme and white pepper. Other options are Thai (i.e., chili, ginger), Mexican and Spanish (i.e., chili, coriander, cumin, parsley), Moroccan and African (i.e., cardamom, clove, saffron), Japanese and Chinese (i.e., wasabi), Turkish and Greek (i.e., anise, cilantro, chili, thyme) and Indian (i.e., curry, turmeric) [285];

- vegetable oils/fats (e.g., sunflower oil, coconut and palm fat) are not recommended [286-288]; olive oil and canola oil may be used sparingly in salad dressings to bridge the transition phase or for higher energy requirements;

- for seasoning, lemon and a variety of vinegars are recommended, along with the use of iodized sea salt [23,197];

- primary liquids should be water and herbal teas (e.g., green, black and hibiscus), and to a lesser extent fresh green smoothies, whereas other liquids (e.g., sports drinks, plantbased protein supplements in connection with PA, plant-based meal replacements) may be used in cases of increased energy and nutritional requirements (e.g., with the precondition of maintaining an intake of $45-80 \mathrm{~g}$ fiber/day, which is considered for a well-designed vegan diet $[71,187,191,199,289,290]$, the recommended daily intake of protein and micronutrients [196]) and with as low as possible an intake of free sugars [280] and saturated fats [291];

- to meet higher energy requirements, individuals may incorporate carbohydrate-rich foods (e.g., dry fruits, whole grain spaghetti, polenta, whole grain bread) in smaller amounts of fat-rich foods (e.g., nuts, seeds and avocado) or mixed sources (e.g., burgers, spreads and dressings, ideally without free sugars and fat);

- the main appropriate cooking methods are moist heat (such as poaching, simmering, boiling, steaming), combination cooking (braising, stewing, pressure cooking), no heat (curing, culturing, fermenting, acidifying, sprouting, soaking, high-speed blending, pureeing, vacuum sealing, juicing (in rare cases, small amounts only), dehydrating) 
and dry heat (air drying/dehydrating, sweating, searing, stir-frying, griddle cooking, baking, roasting, grilling, broiling, sauntering) [292].

Adherence is key in pursuing the effects of a long-term diet given the importance of a day-to-day basis. There is a notion that adopting a vegan diet can be quite demanding, especially since many individuals may face significant problems, social pressure and obstacles in achieving this goal [68]. However, dietary adherence/acceptability was tested in a relatively small, six-month randomized controlled trial ("the New Diets study"), which showed that adherence/acceptability across five different diets, including a vegan diet, was very similar [293]. Self-efficacy, social identification, improved health, body mass/body composition and participation in caring and supportive programs that provide monitoring and relevant feedback progress may further improve long-term adherence [57,62,98,100,101,114,124,294-296].

By adopting a well-designed vegan diet (e.g., high nutrient density), the uncomfortable physical and emotional symptoms of hunger become much less prevalent, and adherence to a healthy diet regime is increased [297]. Informed choice, emotional support, increased accessibility of healthy and affordable food systems and healthy and tasty food preparation methods, especially when eating out, are important determinants that give people the opportunity to improve the quality of their lives [297,298].

In addition, the vegan diet is compatible with sports performance. It has the potential to encourage active people and health and sport experts to be more tolerant when a person expresses interest in implementing a vegan diet. When following a vegan diet for regular exercise or sports performance, the diet needs to be planned carefully, especially in terms of providing (i) enough energy and (ii) proportionally more nutrients. In addition, a well-designed vegan diet for physically active individuals and athletes should primarily be based on conventional unprocessed or minimally processed plant-based foods to ensure the majority of energy and nutrient needs are met. However, the available data suggest that further supplementation in addition to vitamin $\mathrm{B}_{12}, \mathrm{D}$, and EPA/DHA (e.g., plant-protein supplement, plant-based meal replacement, sport drinks and creatine) may offer health and performance benefits or may facilitate individuals' adherence to a vegan $\operatorname{diet}[16,23,71,137,140,143,145,148,149]$.

\section{Barriers to the Implementation of the Vegan Diet/Lifestyle}

The development of a vegan diet as a respected nutritional paradigm faces many barriers that can be divided into at least six groups: (1) lack of education in the vegan field of nutrition by physicians and dietitians, as well as in connection with professional (e.g., conflict of interest) and personal (e.g., eating according to another dietary pattern) "contamination", (2) lack of interest in researching the vegan diet, (3) an obesogenic food environment that increases challenges, (4) believing that a vegan diet is expensive, (5) specific characteristics of a vegan diet/lifestyle and (6) animal-based analogues/alternatives.

\subsection{Lack of Education in the Vegan Field of Nutrition by Physicians and Dietitians}

In Europe [299-302], in the United States' medical schools [303-305] and elsewhere [306-308], an important lack of education about (clinical) nutrition in general is observed. Ironically, we often hear that "nutrition has little or even no impact on health and chronic diseases" [309]. This social situation is rhetorically extremely interesting since poor dietary habits worldwide are the leading contributor to a range of chronic noncommunicable diseases [87,274]. Given this situation, ignoring nutrition or not including advice about healthful eating as a routine part of 21st century medical practice should no longer be defensible [308,310].

However, the gradual wider adoption of a vegan diet in official medicine is also reflected in the news from Wayne State University School of Medicine's Detroit School of Medicine, which prescribes a mandatory four-week whole-food plant-based nutrition education for medical students that also includes interactive cooking presentations [311]. In addition to this encouraging information, the University of Florida's Shands Hospital 
is one of the first healthcare institutions in the United States that provide vegan meal options in inpatient settings (five different options for breakfast, three for lunch, three for dinner and additional chef specialties (e.g., patients also receive educational materials about the role of diet and lifestyle choices and their impact on chronic illnesses) [312], followed by a number of hospitals in the United States that have started inpatient $100 \%$ vegan menus [313].

Additionally, limited data have shown that on average, there is a wide discrepancy between an (unhealthy) lifestyle and the (unhealthy) appearance of the medical profession on the one hand, and what the medical profession (i.e., the authority in the field of health) is supposed to represent in society on the other [314]. Importantly, a lack of knowledge about nutrition often translates into unhealthy dietary patterns and often manifests as inadequate eating habits in professionals themselves [314,315]. Too often, educational resources about nutrition contain one-sided information about a vegan diet, often involving negative and ridiculous connotations and prejudices (e.g., generalizations that it is unnatural and nutritionally inadequate (e.g., because it is necessary to supplement it with vitamin $B_{12}$ ), difficulty maintaining this behavior, inconsistent with modern dietary guidelines and that a vegan diet is eaten mainly by people with ethical or environmental motives). However, students should be taught about both the health benefits of a well-designed vegan diet and the potential risks of a poorly designed vegan diet in a respectful and productive manner [316].

In conclusion, we suggest that both clinical nutrition and a mandatory vegan diet should be an essential part of common undergraduate and postgraduate education in all faculties teaching human nutrition (i.e., medical faculty, biotechnical faculty, faculty of sport, faculty of health sciences).

\subsection{Lack of Financial Interest in Research on the Vegan Diet}

On 22 November 2021, the www.clinicaltrials.gov register [317] included 50 studies available with the "vegan diet" search filter; however, only three studies $(6 \%)$ were industry funded. For comparison, for CVD (e.g., "cardiovascular drug" search filter only) or type 2 diabetes (e.g., "diabetes type 2 drug" search filter only), both of which a well-designed vegan diet may prevent or reverse [67,99-102,114-118], we found 8506 (4382 (51\%) industry funded) studies, respectively.

In addition, public popularity, as depicted by a Google Trends search for the terms "vegan", "vegetarian" and "meat" in Germany, the US and the UK for the period from 2004 to 2019, showed that people are looking for more information on topics related to the term "vegan" [318]. Importantly, with regard to plant-based dietary patterns, the frequency of publication on PubMed from 2000 to 2019 showed that vegan-, vegetarian- and plantbased search terms increased significantly over the years, but more interest was seen for vegetarian-related terms [318]. This may be due to the greater interest of the industry in the popular lacto-vegetarian and Mediterranean diets, which are included within the plant-based diet group. Regardless, both views underscore the increased interest in vegan or plant-based diets in general.

As long as a healthy vegan diet is not part of the healthcare system reward financial framework, nutrition as a science (especially science on vegan diets) cannot receive the respect it deserves or will remain neglected in the medical community with its current status, which slows the development of a vegan lifestyle [315]. In addition, the presented data pose a serious threat not only to the more "extensive" development of the vegan diet within the field of nutrition but also in terms of the objective dissemination of information and the accessibility of healthy vegan meals outside the home environment. Those responsible for nutrition education are encouraged to include a vegan diet in the curriculum, preferably from an expert who will be able to objectively represent the content of this important profession. 


\subsection{Obesogenic Food Environment That Poses an Increasing Challenge}

Industry practices that foster an obesogenic food environment with foods that can be labelled unhealthy, energy-dense, ultra-processed, additives rich and micronutrient deficient are likely the key external contributors to addictive-like overeating and obesity [174,297,298].

In addition, there is a lack of healthy, low-fat, vegan meals on menus in restaurants (e.g., not just a salad bar), canteens and schools, and these meals might be very welcome for anyone on an omnivorous diet or a vegetarian diet, as well as those with allergies (e.g., to milk, eggs, fish or lactose).

Furthermore, the state could subsidize these meals and thus encourage people to consume more plant-based foods, which is very beneficial for health and the environment (i.e., within the framework of climate goals), and is ethical towards animals.

\subsection{Believing That a Vegan Diet Is Expensive}

There is a belief that a vegan diet is expensive, especially if we consider a well-designed vegan diet (e.g., foods that are less dense in energy usually require a higher food volume intake), consumption of mostly organically certified foods or products and eating outside the home often. However, the researchers in one study outside a clinical trial (the GEICO study) setting found that the vegan group reported a decrease in food cost compared with the control group, while reporting a $40-46 \%$ decrease in health-related productivity impairments at work and in regular daily activities [319]. The current state (e.g., December 2021) of food prices in Slovenia in the most commonly available grocery stores also indicates that a well-designed vegan diet can be affordable compared to expenditures on commonly consumed food. In support of this, the prices of oatmeal $(1.1-1.5 € / \mathrm{kg})$, buckwheat $(2.4-3 € / \mathrm{kg})$, wholegrain rice $(3.5 € / \mathrm{kg})$, wholegrain pasta $(1.2-3.4 € / \mathrm{kg})$, legumes (beans $(2-3 € / \mathrm{kg}$ ), lentils $(1.8-2.8 € / \mathrm{kg})$, soy tofu $(4.9-7 € / \mathrm{kg})$, nuts and seeds (flaxseeds $(2.8 € / \mathrm{kg})$, unshelled sesame seeds $(4.8 € / \mathrm{kg}))$, dates $(7.2 € / \mathrm{kg})$, potatoes $(0.8 € / \mathrm{kg})$ and broccoli and cauliflower $(3.7-6.9 € / \mathrm{kg})$ are significantly less expensive or are at least affordable compared with the prices of commonly consumed animal food sources (chicken fillet $(8.8 € / \mathrm{kg})$, eggs $(1.7 € / 10 \mathrm{eggs})$, milk $(1.3 € / \mathrm{L})$, cheese $(5-8 € / \mathrm{kg})$, salmon fillet $(19 € / \mathrm{kg})$ and sardines $(4.8 € / \mathrm{kg}))$ [320-323]. Nevertheless, for a better understanding of the affordability of foods which form the basis of a vegan diet, it is necessary to consider the level of self-sufficiency, both among individuals and nationwide, as well as the future goals of agricultural policy [324,325].

\subsection{Specific Characteristics of a Vegan Diet/Lifestyle}

When referring to a vegan lifestyle, all the structures/aspects of recommendations for a healthy and active lifestyle for the general population should be considered [43-45,326].

Numerous new challenges may arise with demanding changes in vegan dietary behavior. These challenges also include (i) social pressures (e.g., from family members, coworkers and friends who may not support individuals changing to a vegan diet), (ii) expected behaviors (e.g., associated with cultural norms), (iii) many logistical challenges (e.g., meal planning and food preparation), (iv) limited meal choices for a well-designed vegan diet when outside the home environment (e.g., balanced meals in a whole-food, plant-based diet) and (v) an urgent need to acquire new skills (e.g., organization and preparation of delicious balanced meals at home and away from home) with which to successfully change eating habits $[18,98,174,327,328]$.

When individuals are introduced to a vegan diet, they often face challenges related to (1) different food tastes, (2) financial constraints and even (3) diet-specific issues, such as bloating or increased flatulence. Given these factors, predictors of an easier transition to a vegan diet and long-term dietary adherence may include an extensive support system, a positive social environment, convenience and food accessibility [57,98,327,328]. 
For an effective transition to a vegan diet, until such a diet is more widely accepted, the cooperation of the public health system and the support system service of the private sector is needed to ensure continuous integrated, branched and diverse vegan diet services.

\subsection{Animal-Based Analogues/Alternatives}

With the increased popularity of a vegan diet/lifestyle, alternatives to various animalbased products available (e.g., meat analogues, plant-based milk/beverages and vegan cheeses, to name just a few) [283,284,329-331], are more and more present in grocery shops (not only small-sized, specialized shops, but increasingly in commonly available supermarkets) in Slovenia.

In the last decade, vegan alternatives have expanded considerably $[329,330]$. However, caution is needed because they should not be automatically equated within their food group (i.e., coconut oil-based cheese vs. cashew nut-based cheese), nor should they be compared with animal-based food groups (i.e., coconut oil-based or tofu-based cheese vs. dairy-based cheese), both in terms of composition and contribution to nutritional adequacy.

Nevertheless, these vegan products are designed to resemble the taste, appearance and sensory characteristics of traditional animal-based products (i.e., burgers, sausages, milk and cheeses) [329,331]. In addition, these vegan alternatives to animal-based products can be consumed by people adhering to different dietary patterns, either (i) as an aid in the transition to a vegan diet, (ii) as a dietary goal to eating less animal-based foods or (iii) as a low-cost ingredient or food enriching an individual's diet. Moreover, people on a well-designed vegan diet might not always look for specific vegan alternative products in order to mimic the nutritional profile of animal-based products from the same food group.

Importantly, consumers require products that are sustainable, palatable, safe, nutritious, available and affordable [330]. Therefore, not all animal-based food substitutes are healthy, and some of them are even ultra-processed, which can have various effects on health [330]. A recent randomized crossover control study compared the effect of consuming vegan alternative meat as opposed to animal meat on health factors among generally healthy adults. All other dietary (nonproduct) components were similar, and the researchers found no adverse effects on risk factors from the vegan products. However, the "plant phase" lowered the concentration of LDL cholesterol, probably due to lower saturated fat levels, a higher fiber content and plant protein in the vegan alternative meat [331]. In addition, Spanish researchers recently evaluated the nutritional composition of various plant-based cheeses (i.e., made from coconut oil, cashew nuts and tofu). Not surprisingly, coconut oil-based cheese (e.g., high in saturated fat and sodium) cannot be considered healthy [329], while cashew nut- and tofu-based cheeses both showed a healthier nutritional profile. The replacement of dairy-based cheese with cashew nut-, tofu- and plant-based alternatives could reduce intakes of salt and total fats, while replacing the intake of saturated with unsaturated fats [329].

In conclusion, the above-mentioned vegan alternatives to animal-based products have various advantages (i.e., high quality protein and more environmentally sustainable when soy is used) and disadvantages (i.e., some might have a high content of saturated fat, sodium, sugar and other (potentially artificial) sweeteners and flavors, or might have a higher environmental impact). Nowadays, a conscious consumer is faced with ever increasing challenges when selecting healthy vegan products as an alternative to animal ones [330]. At this point, there is still an open question about the long-term health impact of consuming some of these products (e.g., meat analogues, which are on one hand often ultraprocessed, while on the other they contain high amounts of fiber and protein). Therefore, we only recommend that these products (except for products such as tofu-based cheese or plant-based milk/beverages without added fats and sugars) might not be consumed on a daily basis. In addition, they should contain as little as possible of saturated fat, sodium and sugar. 


\section{Conclusions}

Given the critically high prevalence of common chronic diseases, the failure of different approaches to address these public health challenges and encouraging results regarding vegan diets in recent decades, we confidently contend that a well-designed vegan diet combined with a healthy and active lifestyle is a viable option for healthy adults who choose it. The evidence is clear, whereas the concerns are related to an inappropriately designed vegan diet, which is also a problem with any kind of diet (e.g., omnivorous).

A well-designed vegan diet should be energy and nutrient adequate and include proper supplementation, at least with vitamin $B_{12}$, vitamin $D$ in the autumn/winter months and possibly EPA/DHA. In addition, for physically healthy and active individuals (e.g., fitness enthusiasts and competitive vegan athletes) or as a compromise in the present fast-paced lifestyle, using plant-based protein supplements or meal replacements as well as sports drinks and creatine supplementation sparingly might be an option that has important benefits, for example, for body mass management, recovery after PA, adherence to a vegan diet or sport performance without compromising overall health.

In many aspects, but according to the totality of evidence, it is possible to argue that a well-designed vegan diet that is properly supervised by physicians (e.g., familiar with the vegan diet) should also be considered safe and healthy in pregnancy, infancy and childhood, especially in view of the current health challenges of this population and the general population as well due to the trend of current unhealthy diets and their evident consequences. However, more high-quality, long-term studies are needed to suggest further modifications to the vegan diet.

Importantly, we suggest that a well-designed vegan diet should be followed up by an expert in vegan diet and regularly medically supervised for possible nutrient deficiencies (i.e., vitamin $B_{12}$, 25-hydroxyvitamin $\mathrm{D}$, iron and iodine).

Given the above, we strongly believe that placing a well-designed vegan diet for Slovenes will also encourage media activities to regularly and objectively report the results of upcoming scientific studies of vegan diets, thereby indirectly contributing to the greater accessibility of well-designed vegan meals outside the domestic environment (e.g., at work, in educational institutions). In addition, better education, greater social responsibility and public-private sector participation are required for implementing well-designed vegan diets and lifestyles.

Regardless, future studies should include larger samples and long-term prospective randomized controlled studies where different but well-designed diets are compared (i.e., based primarily on unrefined dietary foods). In addition, there is also a lack of welldesigned studies about physically active vegans and vegan athletes, as well as research that includes a vegan diet during pregnancy, breastfeeding, infancy, childhood and among older adults. Finally, we firmly encourage researchers in Slovenia to conduct further reliable scientific research in the field of the "vegan diet/lifestyle".

Funding: This research received no external funding.

Institutional Review Board Statement: Not applicable.

Informed Consent Statement: Not applicable.

Data Availability Statement: Not applicable.

Conflicts of Interest: The author declares no conflict of interest related to this manuscript.

\section{References}

1. Willett, W.; Rockström, J.; Loken, B.; Springmann, M.; Lang, T.; Vermeulen, S.; Garnett, T.; Tilman, D.; DeClerck, F.; Wood, A.; et al. Food in the Anthropocene: The EAT-Lancet Commission on healthy diets from sustainable food systems. Lancet 2019, 393, 447-492. [CrossRef]

2. Greger, M. Primary Pandemic Prevention. Am. J. Lifestyle Med. 2021, 15, 498-505. [CrossRef]

3. Springmann, M.; Spajic, L.; Clark, M.A.; Poore, J.; Herforth, A.; Webb, P.; Rayner, M.; Scarborough, P. The healthiness and sustainability of national and global food based dietary guidelines: Modelling study. BMJ 2020, 370, 2322. [CrossRef] [PubMed] 
4. Storz, M.A. Lifestyle Adjustments in Long-COVID Management: Potential Benefits of Plant-Based Diets. Curr. Nutr. Rep. 2021, 1, 1-12. [CrossRef]

5. Kim, H.; Rebholz, C.M.; Hegde, S.; LaFiura, C.; Raghavan, M.; Lloyd, J.F.; Cheng, S.; Seidelmann, S.B. Plant-based diets, pescatarian diets and COVID-19 severity: A population-based case-control study in six countries. BMJ Nutr. Prev. Heal. 2021, 4. [CrossRef] [PubMed]

6. Stancic, S.; Cullimore, J.; Barnard, N.D. Shoring Up Vaccine Efficacy. Am. J. Med. 2021. [CrossRef] [PubMed]

7. Petersen, K.S.; Freeman, A.M.; Kris-Etherton, P.M.; Williams, K.A.W., Sr.; Reddy, K.R.; Aggarwal, M.; Barnard, N.D.; Ornish, D.; Esselstyn, C.B.E., Jr.; Allen, K.; et al. The Importance of a Healthy Lifestyle in the Era of COVID-19. Int. J. Dis. Reversal Prev. 2021, 3, 16. [CrossRef]

8. United Nation. UN Task Forces Battle Misconceptions of Avian Flu, Mount Indonesian Campaign | I UN News. Available online: https:/ /news.un.org/en/story/2005/10/157792-un-task-forces-battle-misconceptions-avian-flu-mount-indonesian-campaign (accessed on 16 October 2021).

9. Sakkas, H.; Bozidis, P.; Touzios, C.; Kolios, D.; Athanasiou, G.; Athanasopoulou, E.; Gerou, I.; Gartzonika, C. Nutritional Status and the Influence of the Vegan Diet on the Gut Microbiota and Human Health. Medicina 2020, 56, 88. [CrossRef] [PubMed]

10. Bailey, P. What Does It Mean to Consumers? An Exploration into Diets around the World; Ipsos: Paris, France, 2018.

11. Hargreaves, S.M.; Nakano, E.Y.; Zandonadi, R.P. Brazilian Vegetarian Population-Influence of Type of Diet, Motivation and Sociodemographic Variables on Quality of Life Measured by Specific Tool (VEGQOL). Nutrients 2020, 12, 1406. [CrossRef]

12. Dyett, P.A.; Sabaté, J.; Haddad, E.; Rajaram, S.; Shavlik, D. Vegan lifestyle behaviors. An exploration of congruence with health-related beliefs and assessed health indices. Appetite 2013, 67, 119-124. [CrossRef]

13. Radnitz, C.; Beezhold, B.; DiMatteo, J. Investigation of lifestyle choices of individuals following a vegan diet for health and ethical reasons. Appetite 2015, 90, 31-36. [CrossRef] [PubMed]

14. Janssen, M.; Busch, C.; Rödiger, M.; Hamm, U. Motives of consumers following a vegan diet and their attitudes towards animal agriculture. Appetite 2016, 105, 643-651. [CrossRef] [PubMed]

15. Pribis, P.; Pencak, R.C.; Grajales, T. Beliefs and attitudes toward vegetarian lifestyle across generations. Nutrients 2010, 2, 523-531. [CrossRef] [PubMed]

16. Jakše, B.; Jakše, B.; Pinter, S.; Pajek, J.; Mis, N.F. Characteristics of Slovenian Adults in Community-Based Whole-Food Plant-Based Lifestyle Program. J. Nutr. Metab. 2020, 2020, 6950530. [CrossRef]

17. Tso, R.; Forde, C.G. Unintended Consequences: Nutritional Impact and Potential Pitfalls of Switching from Animal- to Plant-Based Foods. Nutrients 2021, 13, 2527. [CrossRef]

18. Davey, D.; Malone, S.; Egan, B. Case Study: Transition to a Vegan Diet in an Elite Male Gaelic Football Player. Sport 2021, 9, 6. [CrossRef] [PubMed]

19. Van Vliet, S.; Burd, N.A.; van Loon, L.J.C. The skeletal muscle anabolic response to plant- versus animal-based protein consumption. J. Nutr. 2015, 145, 1981-1991. [CrossRef]

20. Bailey, H.M.; Stein, H.H. Can the digestible indispensable amino acid score methodology decrease protein malnutrition. Anim. Front. 2019, 9, 18-23. [CrossRef]

21. Chef's Pencil Staff. Most Popular Countries and Cities for Vegans in 2020 (Jan-2021 Update)—Chef's Pencil. Available online: https://www.chefspencil.com/most-popular-countries-and-cities-for-vegans-in-2020-jan-2021-update/ (accessed on 16 October 2021).

22. Loh, H.C.; Hoo, F.K.; Kwan, J.N.; Lim, Y.F.; Looi, I. A Bibliometric Analysis of Global Trends in Vegan-Related Research. Int. J. Dis. Reversal Prev. 2021, 3, 12. [CrossRef]

23. Melina, V.; Craig, W.; Levin, S. Position of the Academy of Nutrition and Dietetics: Vegetarian Diets. J. Acad. Nutr. Diet. 2016, 116, 1970-1980. [CrossRef]

24. Agnoli, C.; Baroni, L.; Bertini, I.; Ciappellano, S.; Fabbri, A.; Papa, M.; Pellegrini, N.; Sbarbati, R.; Scarino, M.L.; Siani, V.; et al. Position paper on vegetarian diets from the working group of the Italian Society of Human Nutrition. Nutr. Metab. Cardiovasc. Dis. 2017, 27, 1037-1052. [CrossRef]

25. British Dietetic Association. British Dietetic Association Confirms Well-Planned Vegan Diets can Support Healthy Living in People of All Ages; The Association of UK Dietitians: Birmingham, UK, 2017.

26. Dietitians of Canada. What You Need to Know About Following a Vegan Eating Plan; Dietitians of Canada: Toronto, ON, Canada, 2020.

27. National Health and Medical Council of Australia. Australian Dietary Guidelines; National Health and Medical Research Council: Canberra, Australia, 2013; ISBN 1864965754.

28. Gomes, S.C.; João, S.; Pinho, P.; Borges, C.; Santos, C.T.; Santos, A.; Design, P.G. National Programme for the Promotion of Healthy Eating Guidelines for a Healthy Vegetarian Diet; National Programme for the Promotions of Healthy Eating: Lisboa, Portugal, 2015; ISBN 978-972-675-228-8.

29. Anderson, L. U.S. Doctors Blast Belgian Misinformation on Vegan Diets; Physicians Committee for Responsible Medicine: Washington, DC, USA, 2019.

30. National Institute of Public Health of Slovenia. Strokovno Mnenje Glede Vegetarijanstva in Kitajske Študije; National Institute of Public Health of Slovenia: Ljubljana, Slovenia, 2011. 
31. Richter, M.; Boeing, H.; Grünewald-Funk, D.; Heseker, H.; Kroke, A.; Leschik-Bonnet, E.; Oberritter, H.; Strohm, D.; Watzl, B. Vegane Ernährung Position der Deutschen Gesellschaft für Ernährung e. V. (DGE). Ernaehrungs Umschau 2016, 63, M262.

32. Gorenc, A. Znanost nad Mite o Prehrani: Ni Dokazov, da bi bil Veganski način Prehranjevanja Bolj Zdrav; Slovenska Tiskovna Agencija-STAznanost: Ljubljana, Slovenia, 2021.

33. Novljan, N.; Boštjančič, V. Res Sprejeti? Vegani, Dokumentarna Oddaja; Televizija Slovenija—RTVSLO.si.: Ljubljana, Slovenia, 2021.

34. Zgonc, D. Prof. Dr. Tadej Battelino: Hlastanje po Zdravju je Tudi Nasilje! Available online: https://www.viva.si/Intervju/15623/ prof-dr-Tadej-Battelino-Hlastanje-po-zdravju-je-tudi-nasilje (accessed on 10 December 2021).

35. Zupan, Š. Zato Morajo Dojenčki in Otroci Jesti Meso. Available online: https://www.bibaleze.si/dojencek/prehrana-zadojencke/vegetarijanska-prehrana-starsi-otroci-dojencek-otrok-vegetarijanci-vegani-meso-ribe-jajca-mleko.html (accessed on 10 December 2021).

36. Lorenčič, M. Rok Orel: Človek je po Naravi Vsejeda Živalska Vrsta. Dnevnik. Available online: https://www.dnevnik.si/104246 6254 (accessed on 11 December 2021).

37. Kozjek Rotovnik, N. Nada Rotovnik Kozjek: Veganstvo ni za Vsakogar. Delo. Available online: https://www.delo.si/polet/nadarotovnik-kozjek-veganstvo-ni-za-vsakogar/ (accessed on 11 December 2021).

38. Dinu, M.; Abbate, R.; Gensini, G.F.; Casini, A.; Sofi, F. Vegetarian, vegan diets and multiple health outcomes: A systematic review with meta-analysis of observational studies. Crit. Rev. Food Sci. Nutr. 2017, 57, 3640-3649. [CrossRef]

39. Hever, J.; Cronise, R.J. Plant-based nutrition for healthcare professionals: Implementing diet as a primary modality in the prevention and treatment of chronic disease. J. Geriatr. Cardiol. 2017, 14, 355-368. [PubMed]

40. Tuso, P.; Ismail, M.H.; Ha, B.P.; Bartolotto, C. Nutritional Update for Physicians: Plant-Based Diets. Perm. J. 2013, 17, 61-66. [CrossRef] [PubMed]

41. Hever, J. Plant-Based Diets: A Physician's Guide. Perm. J. 2016, 20, 15-082. [CrossRef]

42. Storz, M.A. What makes a plant-based diet? a review of current concepts and proposal for a standardized plant-based dietary intervention checklist. Eur. J. Clin. Nutr. 2021. [CrossRef]

43. Robbins, R.; Quan, S.F.; Weaver, M.D.; Bormes, G.; Barger, L.K.; Czeisler, C.A. Examining sleep deficiency and disturbance and their risk for incident dementia and all-cause mortality in older adults across 5 years in the United States. Aging 2021, 13, 3254-3268. [CrossRef]

44. Li, Y.; Schoufour, J.; Wang, D.D.; Dhana, K.; Pan, A.; Liu, X.; Song, M.; Liu, G.; Shin, H.J.; Sun, Q.; et al. Healthy lifestyle and life expectancy free of cancer, cardiovascular disease, and type 2 diabetes: Prospective cohort study. BMJ 2020, 368, I6669. [CrossRef]

45. Rezende, L.F.M.; Sá, T.H.; Mielke, G.I.; Viscondi, J.Y.K.; Rey-López, J.P.; Garcia, L.M.T. All-Cause Mortality Attributable to Sitting Time. Am. J. Prev. Med. 2016, 51, 253-263. [CrossRef]

46. Finucane, M.M.; Stevens, G.A.; Cowan, M.J.; Danaei, G.; Lin, J.K.; Paciorek, C.J.; Singh, G.M.; Gutierrez, H.R.; Lu, Y.; Bahalim, A.N.; et al. National, regional, and global trends in body-mass index since 1980: Systematic analysis of health examination surveys and epidemiological studies with 960 country-years and 9.1 million participants. Lancet 2011, 377, 557-567. [CrossRef]

47. Bentham, J.; Di Cesare, M.; Bilano, V.; Bixby, H.; Zhou, B.; Stevens, G.A.; Riley, L.M.; Taddei, C.; Hajifathalian, K.; Lu, Y.; et al. Worldwide trends in body-mass index, underweight, overweight, and obesity from 1975 to 2016: A pooled analysis of 2416 population-based measurement studies in 128.9 million children, adolescents, and adults. Lancet 2017, 390, $2627-2642$.

48. Ng, M.; Fleming, T.; Robinson, M.; Thomson, B.; Graetz, N.; Margono, C.; Mullany, E.C.; Biryukov, S.; Abbafati, C.; Abera, S.F.; et al. Global, regional, and national prevalence of overweight and obesity in children and adults during 1980-2013: A systematic analysis for the Global Burden of Disease Study 2013. Lancet 2014, 384, 766-781. [CrossRef]

49. Leyden, E.; Hanson, P.; Halder, L.; Rout, L.; Cherry, I.; Shuttlewood, E.; Poole, D.; Loveder, M.; Abraham, J.; Kyrou, I.; et al. Older age does not influence the success of weight loss through the implementation of lifestyle modification. Clin. Endocrinol. 2020, 94, 204-209. [CrossRef]

50. Li, Z.; Heber, D. Sarcopenic obesity in the elderly and strategies for weight management. Nutr. Rev. 2012, 70, 57-64. [CrossRef] [PubMed]

51. Cava, E.; Yeat, N.C.; Mittendorfer, B. Preserving Healthy Muscle during Weight Loss. Adv. Nutr. Int. Rev. J. 2017, 8, 511-519. [CrossRef] [PubMed]

52. Roh, E.; Choi, K.M. Health Consequences of Sarcopenic Obesity: A Narrative Review. Front. Endocrinol. 2020, 11, 332. [CrossRef]

53. Polyzos, S.A.; Margioris, A.N. Sarcopenic obesity. Hormones 2018, 17, 321-331. [CrossRef] [PubMed]

54. Seljak, B.K.; Valenčič, E.; Hristov, H.; Hribar, M.; Lavriša, Ž.; Kušar, A.; Žmitek, K.; Krušič, S.; Gregorič, M.; Blaznik, U.; et al. Inadequate Intake of Dietary Fibre in Adolescents, Adults, and Elderlies: Results of Slovenian Representative SI. Menu Study. Nutrients 2021, 13, 3826. [CrossRef] [PubMed]

55. Gregorič, M.; Blaznik, U.; Turk, V.F.; Delfar, N.; Korošec, A.; Lavtar, D.; Zaletel, M.; Seljak, B.K.; Golja, P.; Kotnik, K.Z.; et al. Različni Vidiki Prehranjevanja Prebivalcev Slovenije (v Starosti od 3 Mesecev do 74 let); Nacionalni Inštitut za Javno Zdravje: Ljubljana, Slovenia, 2020; ISBN 978-961-6945-03-5.

56. Wright, N.; Wilson, L.; Smith, M.; Duncan, B.; McHugh, P. The BROAD study: A randomised controlled trial using a whole food plant-based diet in the community for obesity, ischaemic heart disease or diabetes. Nutr. Diabetes 2017, 7, e256. [CrossRef]

57. Mishra, S.; Xu, J.; Agarwal, U.; Gonzales, J.; Levin, S.; Barnard, N.D. A multicenter randomized controlled trial of a plant-based nutrition program to reduce body weight and cardiovascular risk in the corporate setting: The GEICO study. Eur. J. Clin. Nutr. 2013, 67, 718-724. [CrossRef] 
58. Tran, E.; Dale, H.F.; Jensen, C.; Lied, G.A. Effects of Plant-Based Diets on Weight Status: A Systematic Review. Diabetes Metab. Syndr. Obes. Targets Ther. 2020, 13, 3433-3448. [CrossRef]

59. Jakše, B.; Pinter, S.; Jakše, B.; Bučar Pajek, M.; Pajek, J. Effects of an Ad Libitum Consumed Low-Fat Plant-Based Diet Supplemented with Plant-Based Meal Replacements on Body Composition Indices. Biomed Res. Int. 2017, 2017, 9626390. [CrossRef]

60. Barnard, N.D.; Alwarith, J.; Rembert, E.; Brandon, L.; Nguyen, M.; Goergen, A.; Horne, T.; do Nascimento, G.F.; Lakkadi, K.; Tura, A.; et al. A Mediterranean Diet and Low-Fat Vegan Diet to Improve Body Weight and Cardiometabolic Risk Factors: A Randomized, Cross-over Trial. J. Am. Coll. Nutr. 2021, 1-13. [CrossRef] [PubMed]

61. Barnard, N.D.; Rembert, E.; Freeman, A.; Bradshaw, M.; Holubkov, R.; Kahleova, H. Blood Type Is Not Associated with Changes in Cardiometabolic Outcomes in Response to a Plant-Based Dietary Intervention. J. Acad. Nutr. Diet. 2020, 121, 1080-1086. [CrossRef] [PubMed]

62. Kent, L.; Morton, D.; Hurlow, T.; Rankin, P.; Hanna, A.; Diehl, H. Long-term effectiveness of the community-based Complete Health Improvement Program (CHIP) lifestyle intervention: A cohort study. BMJ Open 2013, 3, e003751. [CrossRef]

63. Benatar, J.R.; Stewart, R.A.H. Cardiometabolic risk factors in vegans; A meta-analysis of observational studies. PLoS ONE 2018, 13, e0209086. [CrossRef] [PubMed]

64. Schick, A.; Boring, J.; Courville, A.; Gallagher, I.; Guo, J.; Howard, R.; Milley, L.; Raisinger, K.; Rozga, I.; Stagliano, M.; et al. Effects of Ad Libitum Low Carbohydrate Versus Low Fat Diets on Body Weight and Fat Mass. Curr. Dev. Nutr. $2020,4,658$. [CrossRef]

65. Koertge, J.; Weidner, G.; Elliott-Eller, M.; Scherwitz, L.; Merritt-Worden, T.A.; Marlin, R.; Lipsenthal, L.; Guarneri, M.; Finkel, R.; Saunders, D.E.; et al. Improvement in medical risk factors and quality of life in women and men with coronary artery disease in the Multicenter Lifestyle Demonstration Project. Am. J. Cardiol. 2003, 91, 1316-1322. [CrossRef]

66. Nugent, S.J.; Rogerson, D.; Ranchordas, M.K.; Broom, D.R. Vegan diet for adults with overweight or obesity. Cochrane Database Syst. Rev. 2020, 19. [CrossRef]

67. Kahleova, H.; Petersen, K.F.; Shulman, G.I.; Alwarith, J.; Rembert, E.; Tura, A.; Hill, M.; Holubkov, R.; Barnard, N.D. Effect of a Low-Fat Vegan Diet on Body Weight, Insulin Sensitivity, Postprandial Metabolism, and Intramyocellular and Hepatocellular Lipid Levels in Overweight Adults. JAMA Netw. Open 2020, 3, e2025454. [CrossRef] [PubMed]

68. Jakše, B.; Jakše, B.; Pajek, J.; Pajek, M. Effects of ad libitum consumed, low-fat, high-fiber plant-based diet supplemented with plant-based meal replacements on cardiovascular risk factors. Food Nutr. Res. 2019, 63. [CrossRef]

69. Jakše, B.; Jakše, B.; Pinter, S.; Pajek, J.; Fidler Mis, N. Whole-Food Plant-Based Lifestyle Program and Decreased Obesity. Am. J. Lifestyle Med. 2020, 155982762094920. [CrossRef]

70. Losasso, C.; Eckert, E.M.; Mastrorilli, E.; Villiger, J.; Mancin, M.; Patuzzi, I.; Di Cesare, A.; Cibin, V.; Barrucci, F.; Pernthaler, J.; et al. Assessing the Influence of Vegan, Vegetarian and Omnivore Oriented Westernized Dietary Styles on Human Gut Microbiota: A Cross Sectional Study. Front. Microbiol. 2018, 9, 317. [CrossRef]

71. Jakše, B.; Jakše, B.; Godnov, U.; Pinter, S. Nutritional, Cardiovascular Health and Lifestyle Status of 'Health Conscious' Adult Vegans and Non-Vegans from Slovenia: A Cross-Sectional Self-Reported Survey. Int. J. Environ. Res. Public Health 2021, $18,5968$. [CrossRef] [PubMed]

72. Kahleova, H.; Rembert, E.; Alwarith, J.; Yonas, W.N.; Tura, A.; Holubkov, R.; Agnello, M.; Chutkan, R.; Barnard, N.D. Effects of a Low-Fat Vegan Diet on Gut Microbiota in Overweight Individuals and Relationships with Body Weight, Body Composition, and Insulin Sensitivity. A Randomized Clinical Trial. Nutrients 2020, 12, 2917. [CrossRef]

73. Hall, K.D.; Guo, J.; Courville, A.B.; Boring, J.; Brychta, R.; Chen, K.Y.; Darcey, V.; Forde, C.G.; Gharib, A.M.; Gallagher, I.; et al. Effect of a plant-based, low-fat diet versus an animal-based, ketogenic diet on ad libitum energy intake. Nat. Med. 2021, 27, 344-353. [CrossRef]

74. Stiegler, P.; Cunliffe, A. The role of diet and exercise for the maintenance of fat-free mass and resting metabolic rate during weight loss. Sports Med. 2006, 36, 239-262. [CrossRef] [PubMed]

75. Odegaard, A.O.; Manson, J.E. Weight and mortality: Why body composition matters. Am. J. Clin. Nutr. 2021, nqaa409. [CrossRef]

76. Bouzas, C.; Bibiloni, M.D.M.; Tur, J.A. Relationship between body image and body weight control in overweight $\geq 55$-year-old adults: A systematic review. Int. J. Environ. Res. Public Health 2019, 16, 1622. [CrossRef]

77. Hausenblas, H.A.; Fallon, E.A. Exercise and body image: A meta-analysis. Psychol. Heal. 2006, 21, 33-47. [CrossRef]

78. Grannell, A.; De Vito, G.; Murphy, J.C.; le Roux, C.W. The influence of skeletal muscle on appetite regulation. Expert Rev. Endocrinol. Metab. 2019, 14, 267-282. [CrossRef] [PubMed]

79. Hall, K.D.; Kahan, S. Maintenance of Lost Weight and Long-Term Management of Obesity. Med. Clin. N. Am. 2018, 102, 183-197. [CrossRef]

80. Turicchi, J.; O’Driscoll, R.; Finlayson, G.; Duarte, C.; Hopkins, M.; Martins, N.; Michalowska, J.; Larsen, T.M.; Van Baak, M.A.; Astrup, A.; et al. Associations between the proportion of fat-free mass loss during weight loss, changes in appetite, and subsequent weight change: Results from a randomized 2-stage dietary intervention trial. Am. J. Clin. Nutr. 2020, 111, 536-544. [CrossRef] [PubMed]

81. Dwyer-Lindgren, L.; Freedman, G.; Engell, R.E.; Fleming, T.D.; Lim, S.S.; Murray, C.J.; Mokdad, A.H. Prevalence of physical activity and obesity in US counties, 2001-2011: A road map for action. Popul. Health Metr. 2013, 11, 7. [CrossRef]

82. Samitz, G.; Egger, M.; Zwahlen, M. Domains of physical activity and all-cause mortality: Systematic review and dose-response meta-analysis of cohort studies. Int. J. Epidemiol. 2011, 40, 1382-1400. [CrossRef] 
83. Johns, D.J.; Hartmann-Boyce, J.; Jebb, S.A.; Aveyard, P. Diet or Exercise Interventions vs Combined Behavioral Weight Management Programs: A Systematic Review and Meta-Analysis of Direct Comparisons. J. Acad. Nutr. Diet. 2014, 114, 1557-1568. [CrossRef]

84. Shaw, K.A.; Gennat, H.C.; O’Rourke, P.; Del Mar, C. Exercise for overweight or obesity. Cochrane Database Syst. Rev. 2006, CD003817. [CrossRef]

85. Bull, F.C.; Al-Ansari, S.S.; Biddle, S.; Borodulin, K.; Buman, M.P.; Cardon, G.; Carty, C.; Chaput, J.P.; Chastin, S.; Chou, R.; et al . World Health Organization 2020 guidelines on physical activity and sedentary behaviour. Br. J. Sports Med. 2020, 54, 1451-1462. [CrossRef]

86. Roth, G.A.; Johnson, C.; Abajobir, A.; Abd-Allah, F.; Abera, S.F.; Abyu, G.; Ahmed, M.; Aksut, B.; Alam, T.; Alam, K.; et al. Global, Regional, and National Burden of Cardiovascular Diseases for 10 Causes, 1990 to 2015. J. Am. Coll. Cardiol. 2017, 70, 1-25. [CrossRef]

87. Meier, T.; Gräfe, K.; Senn, F.; Sur, P.; Stangl, G.I.; Dawczynski, C.; März, W.; Kleber, M.E.; Lorkowski, S. Cardiovascular mortality attributable to dietary risk factors in 51 countries in the WHO European Region from 1990 to 2016: A systematic analysis of the Global Burden of Disease Study. Eur. J. Epidemiol. 2019, 34, 37-55. [CrossRef] [PubMed]

88. American Diabetes Association 8. Cardiovascular Disease and Risk Management. Diabetes Care 2015, 38, S49-S57. [CrossRef]

89. Flora, G.D.; Nayak, M.K. A Brief Review of Cardiovascular Diseases, Associated Risk Factors and Current Treatment Regimes. Curr. Pharm. Des. 2019, 25, 4063-4084. [CrossRef] [PubMed]

90. Zhang, Y.; Hu, G. Dietary Pattern, Lifestyle Factors, and Cardiovascular Diseases. Curr. Nutr. Rep. 2012, 1, 64-72. [CrossRef]

91. Piepoli, M.F.; Hoes, A.W.; Agewall, S.; Albus, C.; Brotons, C.; Catapano, A.L.; Cooney, M.-T.; Corrà, U.; Cosyns, B.; Deaton, C.; et al. 2016 European Guidelines on cardiovascular disease prevention in clinical practice. Eur. Heart J. 2016, 37, $2315-2381$. [CrossRef]

92. Murray, C.J.L.; Abraham, J.; Ali, M.K.; Alvarado, M.; Atkinson, C.; Baddour, L.M.; Bartels, D.H.; Benjamin, E.J.; Bhalla, K.; Birbeck, G.; et al. The State of US health, 1990-2010: Burden of diseases, injuries, and risk factors. JAMA 2013, 310, 591-608. [CrossRef]

93. National Institute of Public Health of the Republic of Slovenia. Nacionalni Program Primarne Preventive Srčno-Žilnih Bolezni; National Institute of Public Health of the Republic of Slovenia: Ljubljana, Slovenia, 2006.

94. National Institute of Public Health of the Republic of Slovenia. 17. maj: Svetovni dan Hipertenzije; National Institute of Public Health: Ljubljana, Slovenia, 2017.

95. Petek Šter, M.; Bulc, M.; Accetto, R.; Petek, D.; Salobir, B.; Žontar, T. Združenje za Arterijsko Hipertenzijo—Slovensko Zdravniško Društvo. In Proceedings of the Protokol Vodenja Arterijske Hipertenzije v Ambulanti Družinske Medicine; Dolenc, P., Ed.; Slovensko Zdravniško Društvo. Sekcija za Hipertenzijo: Ljubljana, Slovenia, 2011; pp. 63-80.

96. Chareonrungrueangchai, K.; Wongkawinwoot, K.; Anothaisintawee, T.; Reutrakul, S. Dietary factors and risks of cardiovascular diseases: An umbrella review. Nutrients 2020, 12, 1088. [CrossRef]

97. Kahleova, H.; Levin, S.; Barnard, N.D. Vegetarian Dietary Patterns and Cardiovascular Disease. Prog. Cardiovasc. Dis. 2018, 61, 54-61. [CrossRef] [PubMed]

98. Jakše, B.; Jakše, B.; Pinter, S.; Jug, B.; Godnov, U.; Pajek, J.; Mis, N.F. Dietary Intakes and Cardiovascular Health of Healthy Adults in Short-, Medium-, and Long-Term Whole-Food Plant-Based Lifestyle Program. Nutrients 2019, 12, 55. [CrossRef]

99. Ornish, D.; Scherwitz, L.W.; Billings, J.H.; Brown, S.E.; Gould, K.L.; Merritt, T.A.; Sparler, S.; Armstrong, W.T.; Ports, T.A.; Kirkeeide, R.L.; et al. Intensive lifestyle changes for reversal of coronary heart disease. JAMA 1998, 280, 2001-2007. [CrossRef] [PubMed]

100. Esselstyn, C.B.; Gendy, G.; Doyle, J.; Golubic, M.; Roizen, M.F. A way to reverse CAD? J. Fam. Pract. 2014, 63, 356-364.

101. Esselstyn, C.B. Updating a 12-year experience with arrest and reversal therapy for coronary heart disease (an overdue requiem for palliative cardiology). Am. J. Cardiol. 1999, 84, 339-341. [CrossRef]

102. Esselstyn, C.B.; Ellis, S.G.; Edendorp, S.V.M.; Crowe, T.D. A Strategy to Arrest and Reverse Coronary Artery Disease: A 5-Year Longitudinal Study of a Single Physician's Practice. J. Fam. Pract. 1995, 41, 560-568. [PubMed]

103. Silberman, A.; Banthia, R.; Estay, I.S.; Kemp, C.; Studley, J.; Hareras, D.; Ornish, D. The effectiveness and efficacy of an intensive cardiac rehabilitation program in 24 sites. Am. J. Health Promot. 2010, 24, 260-266. [CrossRef]

104. Dovč, A.; Mlinšek, G.; Arnol, M.; Oblak, M.; Jakše, B.; Pajek, J. Nutrition intervention for managing dyslipidemia in kidney transplant recipients: Preliminary results of a clinical trial. In Proceedings of the Book of Abstracts: 7th Slovenian Congress of Nephrology, Virtual Congress, 11-14 March 2021; p. 141.

105. Kahleova, H.; Levin, S.; Barnard, N. Cardio-Metabolic Benefits of Plant-Based Diets. Nutrients 2017, 9, 848. [CrossRef] [PubMed]

106. Lee, K.W.; Loh, H.C.; Ching, S.M.; Devaraj, N.K.; Hoo, F.K. Effects of Vegetarian Diets on Blood Pressure Lowering: A Systematic Review with Meta-Analysis and Trial Sequential Analysis. Nutrients 2020, 12, 1604. [CrossRef]

107. Yokoyama, Y.; Nishimura, K.; Barnard, N.D.; Takegami, M.; Watanabe, M.; Sekikawa, A.; Okamura, T.; Miyamoto, Y. Vegetarian Diets and Blood Pressure. JAMA Intern. Med. 2014, 174, 577. [CrossRef] [PubMed]

108. Yokoyama, Y.; Levin, S.M.; Barnard, N.D. Association between plant-based diets and plasma lipids: A systematic review and meta-analysis. Nutr. Rev. 2017, 75, 683-698. [CrossRef]

109. Ornish, D.; Brown, S.E.; Billings, J.H.; Scherwitz, L.W.; Armstrong, W.T.; Ports, T.A.; McLanahan, S.M.; Kirkeeide, R.L.; Gould, K.L.; Brand, R.J. Can lifestyle changes reverse coronary heart disease? The Lifestyle Heart Trial. Lancet 1990, 336, 129-133. [CrossRef] 
110. International Diabetes Federation Facts \& Figures. Available online: https://idf.org/aboutdiabetes/what-is-diabetes/factsfigures.html (accessed on 13 March 2021).

111. National Institute of Public Health of Slovenia Sladkorna bolezen v Sloveniji: Kje smo in Kam Gremo? Available online: https://www.nijz.si/sl/sladkorna-bolezen-v-sloveniji-kje-smo-in-kam-gremo (accessed on 13 March 2021).

112. National Institute of Public Health Of Slovenia 14. November 2020-Svetovni dan Sladkorne Bolezni. Available online: https://www.nijz.si/sl/14-november-2020-svetovni-dan-sladkorne-bolezni (accessed on 17 October 2021).

113. Kelly, J.; Karlsen, M.; Steinke, G. Type 2 Diabetes Remission and Lifestyle Medicine: A Position Statement From the American College of Lifestyle Medicine. Am. J. Lifestyle Med. 2020, 14, 406-419. [CrossRef]

114. Barnard, N.D.; Cohen, J.; Jenkins, D.J.A.; Turner-McGrievy, G.; Gloede, L.; Green, A.; Ferdowsian, H. A low-fat vegan diet and a conventional diabetes diet in the treatment of type 2 diabetes: A randomized, controlled, 74-wk clinical trial. Am. J. Clin. Nutr. 2009, 89, 1588S-1596S. [CrossRef] [PubMed]

115. Anderson, J.W.; Ward, K. High-carbohydrate, high-fiber diets for insulin-treated men with diabetes mellitus. Am. J. Clin. Nutr. 1979, 32, 2312-2321. [CrossRef] [PubMed]

116. Dunaief, D.M.; Fuhrman, J.; Dunaief, J.L.; Ying, G. Glycemic and cardiovascular parameters improved in type 2 diabetes with the high nutrient density (HND) diet. Open J. Prev. Med. 2012, 02, 364-371. [CrossRef]

117. Pischke, C.R.; Weidner, G.; Elliott-Eller, M.; Scherwitz, L.; Merritt-Worden, T.A.; Marlin, R.; Lipsenthal, L.; Finkel, R.; Saunders, D.; McCormac, P.; et al. Comparison of Coronary Risk Factors and Quality of Life in Coronary Artery Disease Patients with Versus without Diabetes Mellitus. Am. J. Cardiol. 2006, 97, 1267-1273. [CrossRef]

118. Kahleova, H.; Tura, A.; Hill, M.; Holubkov, R.; Barnard, N. A Plant-Based Dietary Intervention Improves Beta-Cell Function and Insulin Resistance in Overweight Adults: A 16-Week Randomized Clinical Trial. Nutrients 2018, 10, 189. [CrossRef]

119. Sarver, J.; Khambatta, C.; Barbaro, R.; Chavan, B.; Drozek, D. Retrospective Evaluation of an Online Diabetes Health Coaching Program: A Pilot Study. Am. J. Lifestyle Med. 2019, 15, 466-474. [CrossRef]

120. Rinaldi, S.; Campbell, E.E.; Fournier, J.; O'Connor, C.; Madill, J. A Comprehensive Review of the Literature Supporting Recommendations From the Canadian Diabetes Association for the Use of a Plant-Based Diet for Management of Type 2 Diabetes. Can. J. Diabetes 2016, 40, 471-477. [CrossRef]

121. Barnard, N.D.; Katcher, H.I.; Jenkins, D.J.A.; Cohen, J.; Turner-McGrievy, G. Vegetarian and vegan diets in type 2 diabetes management. Nutr. Rev. 2009, 67, 255-263. [CrossRef]

122. Toumpanakis, A.; Turnbull, T.; Alba-Barba, I. Effectiveness of plant-based diets in promoting well-being in the management of type 2 diabetes: A systematic review. BMJ Open Diabetes Res. Care 2018, 6, e000534. [CrossRef] [PubMed]

123. Barnard, N.D.; Scialli, A.R.; Hurlock, D.; Bertron, P. Diet and sex-hormone binding globulin, dysmenorrhea, and premenstrual symptoms. Obstet. Gynecol. 2000, 95, 245-250.

124. Ornish, D.; Weidner, G.; Fair, W.R.; Marlin, R.; Pettengill, E.B.; Raisin, C.J.; Dunn-Emke, S.; Crutchfield, L.; Jacobs, F.N.; Barnard, R.J.; et al. Intensive lifestyle changes may affect the progression of prostate cancer. J. Urol. 2005, 174, 1065-1070. [CrossRef] [PubMed]

125. Beezhold, B.; Radnitz, C.; Rinne, A.; Di Matteo, J. Vegans report less stress and anxiety than omnivores. Nutr. Neurosci. 2015, 18, 289-296. [CrossRef]

126. Kahleova, H.; McCann, J.; Alwarith, J.; Rembert, E.; Tura, A.; Holubkov, R.; Barnard, N.D. A plant-based diet in overweight adults in a 16-week randomized clinical trial: The role of dietary acid load. Clin. Nutr. ESPEN 2021, 44, 150-158. [CrossRef]

127. Barnard, N.D.; Kahleova, H.; Holtz, D.N.; del Aguila, F.; Neola, M.; Crosby, L.M.; Holubkov, R. The Women's Study for the Alleviation of Vasomotor Symptoms (WAVS): A randomized, controlled trial of a plant-based diet and whole soybeans for postmenopausal women. Menopause 2021, 28, 1150-1156. [CrossRef] [PubMed]

128. Bunner, A.E.; Agarwal, U.; Gonzales, J.F.; Valente, F.; Barnard, N.D. Nutrition intervention for migraine: A randomized crossover trial. J. Headache Pain 2014, 15, 69. [CrossRef]

129. Goldner, B. Six Week Raw Vegan Nutrition Protocol Rapidly Reverses Lupus Nephritis: A Case Series. Int. J. Dis. Reversal Prev. 2019, 1, 11. [CrossRef]

130. Campbell, T.M.; Liebman, S.E. Plant-based dietary approach to stage 3 chronic kidney disease with hyperphosphataemia. BMJ Case Rep. 2019, 12, 232080. [CrossRef]

131. Chiarioni, G.; Popa, S.L.; Dalbeni, A.; Senore, C.; Leucuta, D.C.; Baroni, L.; Fantin, A. Vegan Diet Advice Might Benefit Liver Enzymes in Nonalcoholic Fatty Liver Disease: An Open Observational Pilot Study. J. Gastrointest. Liver Dis. 2021, 30 , 81-87. [CrossRef] [PubMed]

132. McDougall, J.; Bruce, B.; Spiller, G.; Westerdahl, J.; McDougall, M. Effects of a very low-fat, vegan diet in subjects with rheumatoid arthritis. J. Altern. Complement. Med. 2002, 8, 71-75. [CrossRef]

133. Fuhrman, J.H.; Ferreri, D.M. Treatment and Remission of Symptoms in Type 1 Diabetes with a Nutrient-Dense, Plant-Rich (NDPR) Diet: Case Studies. Int. J. Dis. Reversal Prev. 2019, 1, 13. [CrossRef]

134. Goldhamer, A.C.; Klaper, M.; Foorohar, A.; Myers, T.R. Water-only fasting and an exclusively plant foods diet in the management of. BMJ Case Rep. 2015, 2015, bcr2015211582. [CrossRef]

135. Anderson, J.W.; Zeigler, J.A.; Deakins, D.A.; Floore, T.L.; Dillon, D.W.; Wood, C.L.; Oeltgen, P.R.; Whitley, R.J. Metabolic effects of high-carbohydrate, high-fiber diets for insulin-dependent diabetic individuals. Am. J. Clin. Nutr. 1991, 54, 936-943. [CrossRef] 
136. Giem, P.; Beeson, W.L.; Fraser, G.E. The incidence of dementia and intake of animal products: Preliminary findings from the Adventist Health Study. Neuroepidemiology 1993, 12, 28-36. [CrossRef] [PubMed]

137. Wirnitzer, K.C. Vegan Diet in Sports and Exercise-Health Benefits and Advantages to Athletes and Physically Active People: A Narrative Review. Int. J. Sport. Exerc. Med. 2020, 6, 166.

138. Longo, U.G.; Spiezia, F.; Maffulli, N.; Denaro, V. The Best Athletes in Ancient Rome were Vegetarian! J. Sports Sci. Med. 2008, 7, 565. [PubMed]

139. Nebl, J.; Haufe, S.; Eigendorf, J.; Wasserfurth, P.; Tegtbur, U.; Hahn, A. Exercise capacity of vegan, lacto-ovo-vegetarian and omnivorous recreational runners. J. Int. Soc. Sports Nutr. 2019, 16, 23. [CrossRef] [PubMed]

140. Hevia-Larraín, V.; Gualano, B.; Longobardi, I.; Gil, S.; Fernandes, A.L.; Costa, L.A.R.; Pereira, R.M.R.; Artioli, G.G.; Phillips, S.M.; Roschel, H. High-Protein Plant-Based Diet Versus a Protein-Matched Omnivorous Diet to Support Resistance Training Adaptations: A Comparison Between Habitual Vegans and Omnivores. Sports Med. 2021, 51, 1317-1330. [CrossRef]

141. Król, W.; Price, S.; Sliz, D.; Parol, D.; Konopka, M.; Mamcarz, A.; Welnicki, M.; Braksator, W. A Vegan Athlete's Heart-Is It Different? Morphology and Function in Echocardiography. Diagnostics 2020, 10, 477. [CrossRef]

142. Lynch, H.; Johnston, C.; Wharton, C. Plant-Based Diets: Considerations for Environmental Impact, Protein Quality, and Exercise Performance. Nutrients 2018, 10, 1841. [CrossRef]

143. Boutros, G.H.; Landry-Duval, M.A.; Garzon, M.; Karelis, A.D. Is a vegan diet detrimental to endurance and muscle strength? Eur. J. Clin. Nutr. 2020, 74, 1550-1555. [CrossRef]

144. Wirnitzer, K.; Boldt, P.; Lechleitner, C.; Wirnitzer, G.; Leitzmann, C.; Rosemann, T.; Knechtle, B. Health status of female and male vegetarian and vegan endurance runners compared to omnivores-Results from the NURMI study (Step 2). Nutrients 2019, 11, 29. [CrossRef]

145. Monteyne, A.J.; Dunlop, M.V.; Machin, D.J.; Coelho, M.O.C.; Pavis, G.F.; Porter, C.; Murton, A.J.; Abdelrahman, D.R.; Dirks, M.L.; Stephens, F.B.; et al. A mycoprotein based high-protein vegan diet supports equivalent daily myofibrillar protein synthesis rates compared with an isonitrogenous omnivorous diet in older adults: A randomized controlled trial. Br. J. Nutr. 2020, 126, 674-684. [CrossRef]

146. Messina, M.J.; Lynch, H.; Dickinson, J.M.; Reed, K.E. No Difference Between the Effects of Supplementing with Soy Protein Versus Animal Protein on Gains in Muscle Mass and Strength in Response to Resistance Exercise. Int. J. Sport Nutr. Exerc. Metab. 2018, 28, 674-685. [CrossRef]

147. Hernández-Martínez, C.; Fernández-Rodríguez, L.; Soriano, M.A.; Martínez-Sanz, J.M. Case Study: Body Composition Changes Resulting from a Nutritional Intervention on a Professional Vegan Powerlifter. Appl. Sci. 2020, 10, 8675. [CrossRef]

148. Rogerson, D. Vegan diets: Practical advice for athletes and exercisers. J. Int. Soc. Sports Nutr. 2017, 14, 36. [CrossRef]

149. Kaviani, M.; Shaw, K.; Chilibeck, P.D. Benefits of Creatine Supplementation for Vegetarians Compared to Omnivorous Athletes: A Systematic Review. Int. J. Environ. Res. Public Health 2020, 17, 3041. [CrossRef] [PubMed]

150. Great Vegan Athletes All Athletes. Available online: https://www.greatveganathletes.com/all-athletes/ (accessed on 18 March 2021).

151. Bivi, D.; Di Chio, T.; Geri, F.; Morganti, R.; Goggi, S.; Baroni, L.; Mumolo, M.G.; de Bortoli, N.; Peroni, D.G.; Marchi, S.; et al. Raising Children on a Vegan Diet: Parents' Opinion on Problems in Everyday Life. Nutrients 2021, 13, 1796. [CrossRef] [PubMed]

152. Orel, R.; Sedmak, M.; Fidler Mis, N. Vegetarijanska prehrana pri otrocih-praktična navodila. Zdrav. Vestn. 2014, 83, 169-181.

153. Fewtrell, M.; Bronsky, J.; Campoy, C.; Domellöf, M.; Embleton, N.; Fidler Mis, N.; Hojsak, I.; Hulst, J.M.; Indrio, F.; Lapillonne, A.; et al. Complementary Feeding: A Position Paper by the European Society for Paediatric Gastroenterology, Hepatology, and Nutrition (ESPGHAN) Committee on Nutrition. J. Pediatr. Gastroenterol. Nutr. 2017, 64, 119-132. [CrossRef]

154. Merritt, R.J.; Fleet, S.E.; Fifi, A.; Jump, C.; Schwartz, S.; Sentongo, T.; Duro, D.; Rudolph, J.; Turner, J. North American Society for Pediatric Gastroenterology, Hepatology, and Nutrition Position Paper: Plant-based Milks. J. Pediatr. Gastroenterol. Nutr. 2020, 71, 276-281. [CrossRef] [PubMed]

155. De Cosmi, V.; Scaglioni, S.; Agostoni, C. Early taste experiences and later food choices. Nutrients 2017, 9, 107. [CrossRef]

156. Waterland, R.A.; Garza, C. Potential mechanisms of metabolic imprinting that lead to chronic disease. Am. J. Clin. Nutr. 1999, 69, 179-197. [CrossRef] [PubMed]

157. Mangels, A.R.; Messina, V. Considerations in planning vegan diets: Infants. J. Am. Diet. Assoc. 2001, 101, 670-677. [CrossRef]

158. Mahase, E. What does the evidence say about vegan diets in children? BMJ 2021, 375, n2792. [CrossRef]

159. Baroni, L.; Goggi, S.; Battaglino, R.; Berveglieri, M.; Fasan, I.; Filippin, D.; Griffith, P.; Rizzo, G.; Tomasini, C.; Tosatti, M.; et al. Vegan Nutrition for Mothers and Children: Practical Tools for Healthcare Providers. Nutrients 2018, 11, 5. [CrossRef]

160. Sebastiani, G.; Barbero, A.H.; Borrás-Novel, C.; Casanova, M.A.; Aldecoa-Bilbao, V.; Andreu-Fernández, V.; Tutusaus, M.P.; Martínez, S.F.; Roig, M.D.G.; García-Algar, O. The effects of vegetarian and vegan diet during pregnancy on the health of mothers and offspring. Nutrients 2019, 11, 557. [CrossRef]

161. Sutter, D.O.; Bender, N. Nutrient status and growth in vegan children. Nutr. Res. 2021, 91, 13-25. [CrossRef]

162. Tran, B.X.; Dang, K.A.; Le, H.T.; Ha, G.H.; Nguyen, L.H.; Nguyen, T.H.; Tran, T.H.; Latkin, C.A.; Ho, C.S.H.; Ho, R.C.M. Global evolution of obesity research in children and youths: Setting priorities for interventions and policies. Obes. Facts 2019, 12, 137-149. [CrossRef]

163. Weder, S.; Hoffmann, M.; Becker, K.; Alexy, U.; Keller, M. Energy, macronutrient intake, and anthropometrics of vegetarian, vegan, and omnivorous children (1-3 years) in Germany (VeChi diet study). Nutrients 2019, 11, 832. [CrossRef] [PubMed] 
164. Bailey, A.D.L.; Fulgoni, V.L., III; Shah, N.; Patterson, A.C.; Gutierrez-Orozco, F.; Mathews, R.S.; Walsh, K.R. Nutrient Intake Adequacy from Food and Beverage Intake of US Children Aged 1-6 Years from NHANES 2001-2016. Nutrients 2021, $13,827$. [CrossRef]

165. Hovinen, T.; Korkalo, L.; Freese, R.; Skaffari, E.; Isohanni, P.; Niemi, M.; Nevalainen, J.; Gylling, H.; Zamboni, N.; Erkkola, M.; et al. Vegan diet in young children remodels metabolism and challenges the statuses of essential nutrients. EMBO Mol. Med. 2021, 13, e13492. [CrossRef] [PubMed]

166. Desmond, M.A.; Sobiecki, J.G.; Jaworski, M.; Płudowski, P.; Antoniewicz, J.; Shirley, M.K.; Eaton, S.; Ksiązyk, J.; Cortina-Borja, M.; De Stavola, B.; et al. Growth, body composition, and cardiovascular and nutritional risk of 5- to 10-y-old children consuming vegetarian, vegan, or omnivore diets. Am. J. Clin. Nutr. 2021, 113, 1565-1577. [CrossRef]

167. McGill, H.C.; Herderick, E.E.; McMahan, C.A.; Zieske, A.W.; Malcom, G.T.; Tracy, R.E.; Strong, J.P. Atherosclerosis in youth. Minerva Pediatr. 2002, 54, 437-447. [PubMed]

168. Strong, J.P.; Malcom, G.T.; McMahan, C.A.; Tracy, R.E.; Newman, W.P.; Herderick, E.E.; Cornhill, J.F. Prevalence and extent of atherosclerosis in adolescents and young adults: Implications for prevention from the pathobiological determinants of atherosclerosis in youth study. J. Am. Med. Assoc. 1999, 281, 727-735. [CrossRef] [PubMed]

169. Jing, L.; Pulenthiran, A.; Nevius, C.D.; Mejia-Spiegeler, A.; Suever, J.D.; Wehner, G.J.; Kirchner, H.L.; Haggerty, C.M.; Fornwalt, B.K. Impaired right ventricular contractile function in childhood obesity and its association with right and left ventricular changes: A cine DENSE cardiac magnetic resonance study. J. Cardiovasc. Magn. Reson. 2017, 19, 49. [CrossRef]

170. Napoli, C.; D'Armiento, F.P.; Mancini, F.P.; Postiglione, A.; Witztum, J.L.; Palumbo, G.; Palinski, W. Fatty streak formation occurs in human fetal aortas and is greatly enhanced maternal, hypercholesterolemia. Intimal accumulation of low density lipoprotein and its oxidation precede monocyte recruitment into early atheroeclerotic lesions. J. Clin. Investig. 1997, 100, 2680-2690. [CrossRef]

171. Skilton, M.R.; Siitonen, N.; Würtz, P.; Viikari, J.S.A.; Juonala, M.; Seppälä, I.; Laitinen, T.; Lehtimäki, T.; Taittonen, L.; Kähönen, M.; et al. High birth weight is associated with obesity and increased carotid wall thickness in young adults: The cardiovascular risk in young finns study. Arterioscler. Thromb. Vasc. Biol. 2014, 34, 1064-1068. [CrossRef]

172. Macknin, M.; Kong, T.; Weier, A.; Worley, S.; Tang, A.S.; Alkhouri, N.; Golubic, M. Plant-Based, No-Added-Fat or American Heart Association Diets: Impact on Cardiovascular Risk in Obese Children with Hypercholesterolemia and Their Parents. J. Pediatr. 2015, 166, 953-959.e3. [CrossRef]

173. Hall, K.D. Did the Food Environment Cause the Obesity Epidemic? Obesity 2018, 26, 11-13. [CrossRef]

174. Gearhardt, A.N.; Hebebrand, J. The concept of "food addiction" helps inform the understanding of overeating and obesity: Debate Consensus. Am. J. Clin. Nutr. 2021, 113, 274-276. [CrossRef] [PubMed]

175. Amit, M.; Cummings, C.; Grueger, B.; Feldman, M.; Lang, M.; Grabowski, J.; Wong, D.; Greig, A.; Patel, H. Vegetarian diets in children and adolescents. Paediatr. Child Health 2010, 15, 303-314. [PubMed]

176. Redecilla Ferreiro, S.; Moráis López, A.; Moreno Villares, J.M.; Leis Trabazo, R.; José Díaz, J.; Sáenz de Pipaón, M.; Blesa, L.; Campoy, C.; Ángel Sanjosé, M.; Gil Campos, M.; et al. Position paper on vegetarian diets in infants and children. Committee on Nutrition and Breastfeeding of the Spanish Paediatric Association. An. Pediatr. 2019, 92, 306.e1-306.e6. [CrossRef]

177. Lucas, A. Programming by early nutrition: An experimental approach. J. Nutr. 1998, 128, 401S-406S. [CrossRef]

178. Ripple, W.J.; Wolf, C.; Newsome, T.M.; Barnard, P.; Moomaw, W.R. World Scientists' Warning of a Climate Emergency. Bioscience 2019, 70, 8-12. [CrossRef]

179. Crippa, M.; Solazzo, E.; Guizzardi, D.; Monforti-Ferrario, F.; Tubiello, F.N.; Leip, A. Food systems are responsible for a third of global anthropogenic GHG emissions. Nat. Food 2021, 2, 198-209. [CrossRef]

180. Aleksandrowicz, L.; Green, R.; Joy, E.J.M.; Smith, P.; Haines, A. The Impacts of Dietary Change on Greenhouse Gas Emissions, Land Use, Water Use, and Health: A Systematic Review. PLoS ONE 2016, 11, e0165797. [CrossRef]

181. Pieper, M.; Michalke, A.; Gaugler, T. Calculation of external climate costs for food highlights inadequate pricing of animal products. Nat. Commun. 2020, 11, 1-13. [CrossRef] [PubMed]

182. Chai, B.C.; van der Voort, J.R.; Grofelnik, K.; Eliasdottir, H.G.; Klöss, I.; Perez-Cueto, F.J.A. Which Diet Has the Least Environmental Impact on Our Planet? A Systematic Review of Vegan, Vegetarian and Omnivorous Diets. Sustainability 2019, 11, 4110. [CrossRef]

183. Bakaloudi, D.R.; Halloran, A.; Rippin, H.L.; Oikonomidou, A.C.; Dardavesis, T.I.; Williams, J.; Wickramasinghe, K.; Breda, J.; Chourdakis, M. Intake and adequacy of the vegan diet. A systematic review of the evidence. Clin. Nutr. 2020, 40, 3503-3521. [CrossRef]

184. German Nutrition Society; Austrian Nutrition Society; Swiss Society of Nutrition Research the SA for N. Ergaenzlieferung D-A-CH Referenzwerte für die Nährstoffzufuhr [Reference Values for Nutrient Intake], 4th ed.; German Nutrition Society; Austrian Nutrition Society; Swiss Society of Nutrition Research the SA for N: Frankfurt, Germany, 2018; pp. 1-56.

185. EFSA. Dietary Reference Values for nutrients Summary report. EFSA Support. Publ. 2017, 14. [CrossRef]

186. National Institut for Public Health of Slovenia. Referenčne Vrednosti za Energijski vnos ter vnos Hranil. Tabelarična Priporočila za Otroke (od 1. Leta Starosti Naprej), Mladostnike, Odrasle, Starejše Odrasle, Nosečnice ter Doječe Matere; National Institut for Public Health of Slovenia: Ljubljana, Slovenia, 2020.

187. Dunn-Emke, S.R.; Weidner, G.; Pettengill, E.B.; Marlin, R.O.; Chi, C.; Ornish, D.M. Nutrient Adequacy of a Very Low-Fat Vegan Diet. J. Am. Diet. Assoc. 2005, 105, 1442-1446. [CrossRef] 
188. Clarys, P.; Deliens, T.; Huybrechts, I.; Deriemaeker, P.; Vanaelst, B.; De Keyzer, W.; Hebbelinck, M.; Mullie, P. Comparison of nutritional quality of the vegan, vegetarian, semi-vegetarian, pesco-vegetarian and omnivorous diet. Nutrients 2014, 6, 1318-1332. [CrossRef]

189. Schüpbach, R.; Wegmüller, R.; Berguerand, C.; Bui, M.; Herter-Aeberli, I. Micronutrient status and intake in omnivores, vegetarians and vegans in Switzerland. Eur. J. Nutr. 2017, 56, 283-293. [CrossRef] [PubMed]

190. Elorinne, A.L.; Alfthan, G.; Erlund, I.; Kivimäki, H.; Paju, A.; Salminen, I.; Turpeinen, U.; Voutilainen, S.; Laakso, J. Food and nutrient intake and nutritional status of Finnish vegans and non-vegetarians. PLoS ONE 2016, 11, e0148235. [CrossRef]

191. Rizzo, N.S.; Jaceldo-Siegl, K.; Sabate, J.; Fraser, G.E. Nutrient Profiles of Vegetarian and Nonvegetarian Dietary Patterns. J. Acad. Nutr. Diet. 2013, 113, 1610-1619. [CrossRef]

192. Schmidt, J.A.; Crowe, F.L.; Appleby, P.N.; Key, T.J.; Travis, R.C. Serum Uric Acid Concentrations in Meat Eaters, Fish Eaters, Vegetarians and Vegans: A Cross-Sectional Analysis in the EPIC-Oxford Cohort. PLoS ONE 2013, 8, e56339. [CrossRef] [PubMed]

193. Weikert, C.; Trefflich, I.; Menzel, J.; Obeid, R.; Longree, A.; Dierkes, J.; Meyer, K.; Herter-Aeberli, I.; Mai, K.; Stangl, G.I.; et al. Versorgungsstatus mit Vitaminen und Mineralstoffen bei veganer Ernährungsweise. Dtsch. Arztebl. Int. 2020, 117, 575-582.

194. Jeran, M. Evaluation of Diet Quality of Vegans and Omnivores with a Web-Based Application. Master's Thesis, Biotehniška Fakulteta, Univerza v Ljubljani, Ljubljana, Slovenia, 2018.

195. Kristensen, N.B.; Madsen, M.L.; Hansen, T.H.; Allin, K.H.; Hoppe, C.; Fagt, S.; Lausten, M.S.; Gøbel, R.J.; Vestergaard, H.; Hansen, T.; et al. Intake of macro- and micronutrients in Danish vegans. Nutr. J. 2015, 14, 115. [CrossRef]

196. National Institute of Public Health of Slovenia. Referenčne Vrednosti za Energijski vnos ter Vnos Hranil; National Institute of Public: Ljubljana, Slovenia, 2020.

197. Greger, M. A Whole Food Plant-Based Diet Is Effective for Weight Loss: The Evidence. Am. J. Lifestyle Med. 2020, 14, 500-510. [CrossRef] [PubMed]

198. Mariotti, F.; Gardner, C.D. Dietary protein and amino acids in vegetarian diets-A review. Nutrients 2019, 11, 2661. [CrossRef] [PubMed]

199. Karlsen, M.; Rogers, G.; Miki, A.; Lichtenstein, A.; Folta, S.; Economos, C.; Jacques, P.; Livingston, K.; McKeown, N.; Karlsen, M.C.; et al. Theoretical Food and Nutrient Composition of Whole-Food Plant-Based and Vegan Diets Compared to Current Dietary Recommendations. Nutrients 2019, 11, 625. [CrossRef]

200. Green, C.L.; Lamming, D.W.; Fontana, L. Molecular mechanisms of dietary restriction promoting health and longevity. Nat. Rev. Mol. Cell Biol. 2021. [CrossRef] [PubMed]

201. McCarty, M.F. The moderate essential amino acid restriction entailed by low-protein vegan diets may promote vascular health by stimulating FGF21 secretion. Horm. Mol. Biol. Clin. Investig. 2016, 30. [CrossRef] [PubMed]

202. Schoenfeld, B.J.; Aragon, A.A. How much protein can the body use in a single meal for muscle-building? Implications for daily protein distribution. J. Int. Soc. Sports Nutr. 2018, 15, 10. [CrossRef]

203. OPKP Computer Web-Based Software: The Open Platform for Clinical Nutrition (OPEN). Available online: http://www.opkp.si/ sl_SI/fooddiary/diary (accessed on 28 July 2019).

204. Herreman, L.; Nommensen, P.; Pennings, B.; Laus, M.C. Comprehensive overview of the quality of plant- And animal-sourced proteins based on the digestible indispensable amino acid score. Food Sci. Nutr. 2020, 8, 5379. [CrossRef]

205. Craddock, J.C.; Genoni, A.; Strutt, E.F.; Goldman, D.M. Limitations with the Digestible Indispensable Amino Acid Score (DIAAS) with Special Attention to Plant-Based Diets: A Review. Curr. Nutr. Rep. 2021, 10, 93-98. [CrossRef] [PubMed]

206. Reidy, P.T.; Borack, M.S.; Markofski, M.M.; Dickinson, J.M.; Deer, R.R.; Husaini, S.H.; Walker, D.K.; Igbinigie, S.; Robertson, S.M.; Cope, M.B.; et al. Protein supplementation has minimal effects on muscle adaptations during resistance exercise training in young men: A double-blind randomized clinical trial. J. Nutr. 2016, 146, 1660-1669. [CrossRef]

207. Samal, J.R.K.; Samal, I.R. Protein Supplements: Pros and Cons. J. Diet. Suppl. 2018, 15, 365-371. [CrossRef] [PubMed]

208. Morton, R.W.; Murphy, K.T.; McKellar, S.R.; Schoenfeld, B.J.; Henselmans, M.; Helms, E.; Aragon, A.A.; Devries, M.C.; Banfield, L.; Krieger, J.W.; et al. A systematic review, meta-analysis and meta-regression of the effect of protein supplementation on resistance training-induced gains in muscle mass and strength in healthy adults. Br. J. Sports Med. 2018, 52, 376-384. [CrossRef]

209. Young, V.R.; Pellett, P.L. Plant proteins in relation to human protein and amino acid nutrition. Am. J. Clin. Nutr. 1994, 59, 1203S-1212S. [CrossRef] [PubMed]

210. Moughan, P.J.; Rutherfurd, S.M. Gut luminal endogenous protein: Implications for the determination of ileal amino acid digestibility in humans. Br. J. Nutr. 2012, 108, S258-S263. [CrossRef] [PubMed]

211. Munro, H.N. Regulation of protein metabolism. Acta Anaesthesiol. Scand. 1974, 55, 66-73. [CrossRef] [PubMed]

212. $\mathrm{Wu}, \mathrm{G}$. Important roles of dietary taurine, creatine, carnosine, anserine and 4-hydroxyproline in human nutrition and health. Amino Acids 2020, 52, 329-360. [CrossRef] [PubMed]

213. Hou, Y.; He, W.; Hu, S.; Wu, G. Composition of polyamines and amino acids in plant-source foods for human consumption. Amino Acids 2019, 51, 1153-1165. [CrossRef] [PubMed]

214. Kreider, R.B.; Stout, J.R. Creatine in Health and Disease. Nutrients 2021, 13, 447. [CrossRef]

215. Jäger, R.; Purpura, M.; Shao, A.; Inoue, T.; Kreider, R.B. Analysis of the efficacy, safety, and regulatory status of novel forms of creatine. Amino Acids 2011, 40, 1369. [CrossRef] 
216. Blancquaert, L.; Baguet, A.; Bex, T.; Volkaert, A.; Everaert, I.; Delanghe, J.; Petrovic, M.; Vervaet, C.; De Henauw, S.; ConstantinTeodosiu, D.; et al. Changing to a vegetarian diet reduces the body creatine pool in omnivorous women, but appears not to affect carnitine and carnosine homeostasis: A randomised trial. Br. J. Nutr. 2018, 119, 759-770. [CrossRef]

217. Lourenço, R.; Camilo, M.E. Taurine: A conditionally essential amino acid in humans? An overview in health and disease. Nutr. Hosp. 2002, 17, 262-270.

218. Stabler, S.P.; Allen, R.H. Vitamin B12 deficiency as a worldwide problem. Annu. Rev. Nutr. 2004, 24, 299-326. [CrossRef]

219. Obeid, R.; Murphy, M.; Solé-Navais, P.; Yajnik, C. Cobalamin status from pregnancy to early childhood: Lessons from global experience. Adv. Nutr. 2017, 8, 971-979. [CrossRef] [PubMed]

220. Allen, L.H. How common is vitamin B-12 deficiency? Am. J. Clin. Nutr. 2009, 89, 693S-696S. [CrossRef] [PubMed]

221. Mariotti, F. Vegetarian and Plant-Based Diets in Health and Disease Prevention, 1st ed.; Academic Press: London, UK, 2019. ISBN 9780128039687.

222. Hankey, G.J. B vitamins for stroke prevention. Stroke Vasc. Neurol. 2018, 3, 51-58. [CrossRef]

223. Paul, C.; Brady, D.M. Comparative Bioavailability and Utilization of Particular Forms of B12 Supplements with Potential to Mitigate B12-related Genetic Polymorphisms. Integr. Med. 2017, 16, 42-49.

224. Ströhle, A.; Richter, M.; González-Gross, M.; Neuhäuser-Berthold, M.; Wagner, K.H.; Leschik-Bonnet, E.; Egert, S. The Revised D-A-CH-Reference Values for the Intake of Vitamin B 12: Prevention of Deficiency and Beyond. Mol. Nutr. Food Res. 2019, 63, e1801178. [CrossRef]

225. Palacios, C.; Gonzalez, L. Is vitamin D deficiency a major global public health problem? J. Steroid Biochem. Mol. Biol. 2014, 144, 138-145. [CrossRef] [PubMed]

226. Hribar, M.; Hristov, H.; Lavriša, Ž.; Seljak, B.K.; Gregorič, M.; Blaznik, U.; Žmitek, K.; Pravst, I. Vitamin D Intake in Slovenian Adolescents, Adults, and the Elderly Population. Nutrients 2021, 13, 3528. [CrossRef]

227. Hribar, M.; Hristov, H.; Gregorič, M.; Blaznik, U.; Zaletel, K.; Oblak, A.; Osredkar, J.; Kušar, A.; Žmitek, K.; Rogelj, I.; et al. Nutrihealth Study: Seasonal Variation in Vitamin D Status Among the Slovenian Adult and Elderly Population. Nutrients 2020, 12, 1838. [CrossRef]

228. Charoenngam, N.; Holick, M.F. Immunologic effects of vitamin d on human health and disease. Nutrients 2020, $12,2097$. [CrossRef] [PubMed]

229. Roth, D.E.; Abrams, S.A.; Aloia, J.; Bergeron, G.; Bourassa, M.W.; Brown, K.H.; Calvo, M.S.; Cashman, K.D.; Combs, G.; De-Regil, L.M.; et al. Global prevalence and disease burden of vitamin D deficiency: A roadmap for action in low- and middle-income countries. Ann. N. Y. Acad. Sci. 2018, 1430, 44. [CrossRef]

230. Crowe, F.L.; Steur, M.; Allen, N.E.; Appleby, P.N.; Travis, R.C.; Key, T.J. Plasma concentrations of 25-hydroxyvitamin D in meat eaters, fish eaters, vegetarians and vegans: Results from the EPIC-Oxford study. Public Health Nutr. 2011, 14, 340-346. [CrossRef]

231. Allès, B.; Baudry, J.; Méjean, C.; Touvier, M.; Péneau, S.; Hercberg, S.; Kesse-Guyot, E. Comparison of Sociodemographic and Nutritional Characteristics between Self-Reported Vegetarians, Vegans, and Meat-Eaters from the NutriNet-Santé Study. Nutrients 2017, 9, 1023. [CrossRef]

232. Jakše, B.; Jakše, B.; Mis, N.F.; Jug, B.; Šajber, D.; Godnov, U.; Čuk, I. Nutritional Status and Cardiovascular Health in Female Adolescent Elite-Level Artistic Gymnasts and Swimmers: A Cross-Sectional Study of 31 Athletes. J. Nutr. Metab. 2021, 8810548, 15. [CrossRef] [PubMed]

233. Chan, J.; Jaceldo-Siegl, K.; Fraser, G.E. Serum 25-hydroxyvitamin D status of vegetarians, partial vegetarians, and nonvegetarians: The Adventist Health Study-2. Am. J. Clin. Nutr. 2009, 89, 1686S. [CrossRef] [PubMed]

234. Pfeifer, M.; Siuka, D.; Pravst, I. Priporočila za Nadomeščanje Holekalciferola (vitamina D3) v Obdobjih Respiratornih Okužb in za Nadomeščanje Holekalciferola pri Posameznikih s COVID-19; University Medical Centre Ljubljana: Ljubljana, Slovenia, 2020.

235. Ekwaru, J.P.; Zwicker, J.D.; Holick, M.F.; Giovannucci, E.; Veugelers, P.J. The importance of body weight for the dose response relationship of oral vitamin D supplementation and serum 25-hydroxyvitamin D in healthy volunteers. PLoS ONE 2014, 9 , e111265. [CrossRef]

236. American Geriatrics Society Workgroup on Vitamin D Supplementation for Older Adults. American Geriatrics Society Workgroup on Vitamin D Supplementation for Older Adults Recommendations abstracted from the american geriatrics society consensus statement on vitamin D for prevention of falls and their consequences. J. Am. Geriatr. Soc. 2014, 62, 147-152. [CrossRef] [PubMed]

237. Saunders, A.V.; Davis, B.C.; Garg, M.L. Omega-3 polyunsaturated fatty acids and vegetarian diets. Med. J. Aust. 2013, 199, S22-S26. [CrossRef]

238. Raatz, S.K.; Bibus, D.; Thomas, W.; Kris-Etherton, P. Human Nutrition and Metabolism: Total fat intake modifies plasma fatty acid composition in humans. J. Nutr. 2001, 131, 231-234. [CrossRef] [PubMed]

239. Welch, A.A.; Shakya-Shrestha, S.; Lentjes, M.A.H.; Wareham, N.J.; Khaw, K.T. Dietary intake and status of n-3 polyunsaturated fatty acids in a population of fish-eating and non-fish-eating meat-eaters, vegetarians, and vegans and the precursor-product ratio of $\alpha$-linolenic acid to long-chain $\mathrm{n}-3$ polyunsaturated fatty acids: Results from the EPIC-Norfolk cohort. Am. J. Clin. Nutr. 2010, 92, 1040-1051.

240. Burns-Whitmore, B.; Froyen, E.; Heskey, C.; Parker, T.; Pablo, G.S. Alpha-linolenic and linoleic fatty acids in the vegan diet: Do they require dietary reference intake/adequate intake special consideration? Nutrients 2019, 11, 2365. [CrossRef] 
241. Koletzko, B.; Reischl, E.; Tanjung, C.; Gonzalez-Casanova, I.; Ramakrishnan, U.; Meldrum, S.; Simmer, K.; Heinrich, J.; Demmelmair, H. FADS1 and FADS2 Polymorphisms Modulate Fatty Acid Metabolism and Dietary Impact on Health. Annu. Rev. Nutr. 2019, 39, 21-44. [CrossRef]

242. Koletzko, B.; Godfrey, K.M.; Poston, L.; Szajewska, H.; van Goudoever, J.B.; de Waard, M.; Brands, B.; Grivell, R.M.; Deussen, A.R.; Dodd, J.M.; et al. Nutrition During Pregnancy, Lactation and Early Childhood and its Implications for Maternal and Long-Term Child Health: The Early Nutrition Project Recommendations. Ann. Nutr. Metab. 2019, 74, 93-106. [CrossRef] [PubMed]

243. Ågren, J.J.; Törmälä, M.L.; Nenonen, M.T.; Hänninen, O.O. Fatty acid composition of erythrocyte, platelet, and serum lipids in strict vegans. Lipids 1995, 30, 365-369. [CrossRef]

244. Vannice, G.; Rasmussen, H. Position of the academy of nutrition and dietetics: Dietary fatty acids for healthy adults. J. Acad. Nutr. Diet. 2014, 114, 136-153. [CrossRef]

245. Tan, Z.S.; Harris, W.S.; Beiser, A.S.; Au, R.; Himali, J.J.; Debette, S.; Pikula, A.; DeCarli, C.; Wolf, P.A.; Vasan, R.S.; et al. Red blood cell omega-3 fatty acid levels and markers of accelerated brain aging. Neurology 2012, 78, 658-664. [CrossRef]

246. Witte, A.V.; Kerti, L.; Hermannstädter, H.M.; Fiebach, J.B.; Schreiber, S.J.; Schuchardt, J.P.; Hahn, A.; Flöel, A. Long-chain omega-3 fatty acids improve brain function and structure in older adults. Cereb. Cortex 2014, 24, 3059-3068. [CrossRef]

247. Sobiecki, J.G.; Appleby, P.N.; Bradbury, K.E.; Key, T.J. High compliance with dietary recommendations in a cohort of meat eaters, fish eaters, vegetarians, and vegans: Results from the European Prospective Investigation into Cancer and Nutrition-Oxford study. Nutr. Res. 2016, 36, 464-477. [CrossRef]

248. Fallon, N.; Dillon, S.A. Low Intakes of Iodine and Selenium Amongst Vegan and Vegetarian Women Highlight a Potential Nutritional Vulnerability. Front. Nutr. 2020, 0, 72. [CrossRef] [PubMed]

249. Balk, E.M.; Adam, G.P.; Langberg, V.N.; Earley, A.; Clark, P.; Ebeling, P.R.; Mithal, A.; Rizzoli, R.; Zerbini, C.A.F.; Pierroz, D.D.; et al. Global dietary calcium intake among adults: A systematic review. Osteoporos. Int. 2017, 28, 3315-3324. [CrossRef]

250. Willett, W.C.; Ludwig, D.S. Milk and Health. N. Engl. J. Med. 2020, 127, 2542-2545. [CrossRef] [PubMed]

251. Menzel, J.; Abraham, K.; Stangl, G.I.; Ueland, P.M.; Obeid, R.; Schulze, M.B.; Herter-Aeberli, I.; Schwerdtle, T.; Weikert, C. Vegan Diet and Bone Health-Results from the Cross-Sectional RBVD Study. Nutrients 2021, 13, 685. [CrossRef] [PubMed]

252. Hsu, E. Plant-based diets and bone health: Sorting through the evidence. Curr. Opin. Endocrinol. Diabetes. Obes. 2020, $27,248-252$. [CrossRef] [PubMed]

253. Tong, T.Y.N.; Appleby, P.N.; Armstrong, M.E.G.; Fensom, G.K.; Knuppel, A.; Papier, K.; Perez-Cornago, A.; Travis, R.C.; Key, T.J. Vegetarian and vegan diets and risks of total and site-specific fractures: Results from the prospective EPIC-Oxford study. BMC Med. 2020, 18, 353. [CrossRef] [PubMed]

254. Li, T.; Li, Y.; Wu, S. Comparison of human bone mineral densities in subjects on plant-based and omnivorous diets: A systematic review and meta-analysis. Arch. Osteoporos. 2021, 16, 95. [CrossRef]

255. Jakse, B.; Sekulic, D.; Jakse, B.; Cuk, I.; Sajber, D. Bone health among indoor female athletes and associated factors; a cross-sectional study. Res. Sport. Med. 2019, 28, 314-323. [CrossRef] [PubMed]

256. Burckhardt, P. Calcium revisited, part III: Effect of dietary calcium on BMD and fracture risk. Bonekey Rep. 2015, 4, 708. [CrossRef]

257. Melse-Boonstra, A. Bioavailability of Micronutrients From Nutrient-Dense Whole Foods: Zooming in on Dairy, Vegetables, and Fruits. Front. Nutr. 2020, 7, 101. [CrossRef]

258. Heaney, R.P.; Weaver, C.M.; Hinders, S.; Martin, B.; Packard, P.T. Absorbability of Calcium from Brassica Vegetables: Broccoli, Bok Choy, and Kale. J. Food Sci. 1993, 58, 1378-1380. [CrossRef]

259. Yang, W.; Li, B.; Dong, X.; Zhang, X.Q.; Zeng, Y.; Zhou, J.L.; Tang, Y.H.; Xu, J.J. Is heme iron intake associated with risk of coronary heart disease? A meta-analysis of prospective studies. Eur. J. Nutr. 2014, 53, 395-400. [CrossRef] [PubMed]

260. Bao, W.; Rong, Y.; Rong, S.; Liu, L. Dietary iron intake, body iron stores, and the risk of type 2 diabetes: A systematic review and meta-analysis. BMC Med. 2012, 10, 119. [CrossRef]

261. Fonseca-Nunes, A.; Jakszyn, P.; Agudo, A. Iron and cancer risk-a systematic review and meta-analysis of the epidemiological evidence. Cancer Epidemiol. Biomarkers Prev. 2014, 23, 12-31. [CrossRef]

262. Posen, J.S. Iron and vegetarian diets. Med. J. Aust. 2013, 199, S11-S16.

263. Diaz, M.; Rosado, J.L.; Allen, L.H.; Abrams, S.; García, O.P. The efficacy of a local ascorbic acid-rich food in improving iron absorption from Mexican diets: A field study using stable isotopes. Am. J. Clin. Nutr. 2003, 78, 436-440. [CrossRef]

264. Gautam, S.; Platel, K.; Srinivasan, K. Higher Bioaccessibility of iron and zinc from food grains in the presence of garlic and onion. J. Agric. Food Chem. 2010, 58, 8426-8429. [CrossRef]

265. Thankachan, P.; Walczyk, T.; Muthayya, S.; Kurpad, A.V.; Hurrell, R.F. Iron absorption in young Indian women: The interaction of iron status with the influence of tea and ascorbic acid 1-3. Am. J. Clin. Nutr. 2008, 87, 881-886. [CrossRef]

266. Schlemmer, U.; Frølich, W.; Prieto, R.M.; Grases, F. Phytate in foods and significance for humans: Food sources, intake, processing, bioavailability, protective role and analysis. Mol. Nutr. Food Res. 2009, 53, S330-S375. [CrossRef] [PubMed]

267. Lönnerdal, B. Dietary factors influencing zinc absorption. J. Nutr. 2000, 130, 1378S-1383S. [CrossRef]

268. Biban, B.G.; Lichiardopol, C. Iodine Deficiency, Still a Global Problem? Curr. Heal. Sci. J. 2017, 43, $103-111$.

269. Eveleigh, E.R.; Coneyworth, L.J.; Avery, A.; Welham, S.J.M. Vegans, vegetarians, and omnivores: How does dietary choice influence iodine intake? A systematic review. Nutrients 2020, 12, 1606. [CrossRef] [PubMed]

270. Štimec, M.; Kobe, H.; Smole, K.; Kotnik, P.; Širca-Čampa, A.; Zupančič, M.; Battelino, T.; Kržišnik, C.; Fidler Mis, N. Adequate iodine intake of Slovenian adolescents is primarily attributed to excessive salt intake. Nutr. Res. 2009, 29, 888-896. [CrossRef] 
271. World Health Organization. Nutrition, Physical Activity and Obesity Slovenia; World Health Organization, Regional Office for Europe: Copenhagen, Denmark, 2013.

272. Andersson, M.; Karumbunathan, V.; Zimmermann, M.B. Global iodine status in 2011 and trends over the past decade. J. Nutr. 2012, 142, 744-750. [CrossRef] [PubMed]

273. Zimmermann, M.B.; Andersson, M. Update on iodine status worldwide. Curr. Opin. Endocrinol. Diabetes. Obes. 2012, 19, 382-387. [CrossRef]

274. Afshin, A.; Sur, P.J.; Fay, K.A.; Cornaby, L.; Ferrara, G.; Salama, J.S.; Mullany, E.C.; Abate, K.H.; Abbafati, C.; Abebe, Z.; et al. Health effects of dietary risks in 195 countries, 1990-2017: A systematic analysis for the Global Burden of Disease Study 2017. Lancet 2019, 393, 1958-1972. [CrossRef]

275. Partearroyo, T.; de Samaniego-Vaesken, M.L.; Ruiz, E.; Aranceta-Bartrina, J.; Gil, Á.; González-Gross, M.; Ortega, R.M.; SerraMajem, L.; Varela-Moreiras, G. Sodium intake from foods exceeds recommended limits in the spanish population: The ANIBES study. Nutrients 2019, 11, 2451. [CrossRef] [PubMed]

276. Monteiro, C.A.; Cannon, G.; Moubarac, J.C.; Levy, R.B.; Louzada, M.L.C.; Jaime, P.C. The UN Decade of Nutrition, the NOVA food classification and the trouble with ultra-processing. Public Health Nutr. 2018, 21, 5-17. [CrossRef]

277. Meinhardt, A.K.; Müller, A.; Burcza, A.; Greiner, R. Influence of cooking on the iodine content in potatoes, pasta and rice using iodized salt. Food Chem. 2019, 301, 125293. [CrossRef] [PubMed]

278. Hu, W.; Zhao, C.; Hu, H.; Yin, S. Food Sources of Selenium and Its Relationship with Chronic Diseases. Nutrients 2021, $13,1739$. [CrossRef] [PubMed]

279. Scientific Advisory Committee on Nutrition. Carbohydrates and Health; The Stationery Office: London, UK, 2015.

280. Fidler Mis, N.; Braegger, C.; Bronsky, J.; Campoy, C.; Domellöf, M.; Embleton, N.D.; Hojsak, I.; Hulst, J.; Indrio, F.; Lapillonne, A.; et al. Sugar in Infants, Children and Adolescents: A Position Paper of the European Society for Paediatric Gastroenterology, Hepatology and Nutrition Committee on Nutrition. J. Pediatr. Gastroenterol. Nutr. 2017, 65, 681-696. [CrossRef]

281. Śliż, D.; Parol, D.; Wełnicki, M.; Chomiuk, T.; Grabowska, I.; Dąbrowska, D.; Król, W.; Price, S.; Braksator, W.; Mamcarz, A. Macronutrient intake, carbohydrate metabolism and cholesterol in Polish male amateur athletes on a vegan diet. Nutr. Bull. 2021, 46, 120-127. [CrossRef]

282. Fuhrman, J.H.; Ferreri, D.M. Nuts And Seeds For Heart Disease Prevention. Int. J. Dis. Reversal Prev. 2020, 2, 8. [CrossRef]

283. Sethi, S.; Tyagi, S.K.; Anurag, R.K. Plant-based milk alternatives an emerging segment of functional beverages: A review. J. Food Sci. Technol. 2016, 53, 3408-3423. [CrossRef]

284. Craig, W.J.; Fresán, U. International Analysis of the Nutritional Content and a Review of Health Benefits of Non-Dairy Plant-Based Beverages. Nutrients 2021, 13, 842. [CrossRef] [PubMed]

285. Carlsen, M.H.; Halvorsen, B.L.; Holte, K.; Bøhn, S.K.; Dragland, S.; Sampson, L.; Willey, C.; Senoo, H.; Umezono, Y.; Sanada, C.; et al. The total antioxidant content of more than 3100 foods, beverages, spices, herbs and supplements used worldwide. Nutr. J. 2010, 9, 3. [CrossRef]

286. Estruch, R.; Ros, E.; Salas-Salvadó, J.; Covas, M.-I.; Corella, D.; Arós, F.; Gómez-Gracia, E.; Ruiz-Gutiérrez, V.; Fiol, M.; Lapetra, J.; et al. Primary Prevention of Cardiovascular Disease with a Mediterranean Diet. N. Engl. J. Med. 2013, 368, 1279-1290. [CrossRef] [PubMed]

287. Esselstyn, C.B., Jr. Is Oil Healthy? Int. J. Dis. Reversal Prev. 2019, 1, 3. [CrossRef]

288. Neelakantan, N.; Seah, J.Y.H.; Van Dam, R.M. The Effect of Coconut Oil Consumption on Cardiovascular Risk Factors: A Systematic Review and Meta-Analysis of Clinical Trials. Circulation 2020, 141, 803-814. [CrossRef] [PubMed]

289. Jakše, B.; Jakše, B.; Pinter, S.; Pajek, J.; Godnov, U.; Fidler Mis, N. Nutrient and Food Intake of Participants in a Whole-Food Plant-Based Lifestyle Program. J. Am. Coll. Nutr. 2020, 40, 333-348. [CrossRef]

290. Dewell, A.; Weidner, G.; Sumner, M.D.; Chi, C.S.; Ornish, D. A Very-Low-Fat Vegan Diet Increases Intake of Protective Dietary Factors and Decreases Intake of Pathogenic Dietary Factors. J. Am. Diet. Assoc. 2008, 108, 347-356. [CrossRef] [PubMed]

291. Kris-Etherton, P.M.; Krauss, R.M. Public health guidelines should recommend reducing saturated fat consumption as much as possible: YES. Am. J. Clin. Nutr. 2020, 112, 13-18. [CrossRef]

292. Rouxbe Online Culinary School. Available online: https:// rouxbe.com/ (accessed on 18 October 2021).

293. Moore, W.J.; McGrievy, M.E.; Turner-McGrievy, G.M. Dietary adherence and acceptability of five different diets, including vegan and vegetarian diets, for weight loss: The New DIETs study. Eat. Behav. 2015, 19, 33-38. [CrossRef]

294. Cruwys, T.; Norwood, R.; Chachay, V.S.; Ntontis, E.; Sheffield, J. “An Important Part of Who I am”: The Predictors of Dietary Adherence among Weight-Loss, Vegetarian, Vegan, Paleo, and Gluten-Free Dietary Groups. Nutrients 2020, 12, 970. [CrossRef]

295. Brandt, C.J.; Clemensen, J.; Nielsen, J.B.; Søndergaard, J. Drivers for successful long-term lifestyle change, the role of e-health: A qualitative interview study. BMJ Open 2018, 8, 17466. [CrossRef]

296. Turner-McGrievy, G.M.; Barnard, N.D.; Scialli, A.R. A two-year randomized weight loss trial comparing a vegan diet to a more moderate low-fat diet. Obesity 2007, 15, 2276-2281. [CrossRef] [PubMed]

297. Fuhrman, J.; Sarter, B.; Glaser, D.; Acocella, S. Changing perceptions of hunger on a high nutrient density diet. Nutr. J. $2010,9$. [CrossRef]

298. Fuhrman, J. The Hidden Dangers of Fast and Processed Food*. Am. J. Lifestyle Med. 2018, 12, 375-381. [CrossRef] [PubMed]

299. Chung, M.; Van Buul, V.J.; Wilms, E.; Nellessen, N.; Brouns, F.J.P.H. Nutrition education in European medical schools: Results of an international survey. Eur. J. Clin. Nutr. 2014, 68, 844-846. [CrossRef] [PubMed] 
300. Dumic, A.; Miskulin, M.; Pavlovic, N.; Orkic, Z.; Bilic-Kirin, V.; Miskulin, I. The Nutrition Knowledge of Croatian General Practitioners. J. Clin. Med. 2018, 7, 178. [CrossRef] [PubMed]

301. Grammatikopoulou, M.G.; Katsouda, A.; Lekka, K.; Tsantekidis, K.; Bouras, E.; Kasapidou, E.; Poulia, K.A.; Chourdakis, M. Is continuing medical education sufficient? Assessing the clinical nutrition knowledge of medical doctors. Nutrition 2019, 57, 69-73. [CrossRef]

302. Hyska, J.; Mersini, E.; Mone, I.; Bushi, E.; Sadiku, E.; Hoti, K.; Bregu, A. Assessment of knowledge, attitudes and practices about public health nutrition among students of the University of Medicine in Tirana, Albania. South East. Eur. J. Public Heal. 2014. [CrossRef]

303. Devries, S.; Dalen, J.E.; Eisenberg, D.M.; Maizes, V.; Ornish, D.; Prasad, A.; Sierpina, V.; Weil, A.T.; Willett, W. A deficiency of nutrition education in medical training. Am. J. Med. 2014, 127, 804-806. [CrossRef]

304. Crowley, J.; Ball, L.; Hiddink, G.J. Nutrition in medical education: A systematic review. Lancet Planet. Health 2019, 3, e379-e389. [CrossRef]

305. Devries, S.; Agatston, A.; Aggarwal, M.; Aspry, K.E.; Esselstyn, C.B.; Kris-Etherton, P.; Miller, M.; O’Keefe, J.H.; Ros, E.; Rzeszut, A.K.; et al. A Deficiency of Nutrition Education and Practice in Cardiology. Am. J. Med. 2017, 130, 1298-1305. [CrossRef] [PubMed]

306. Sanne, I.; Bjørke-Monsen, A.L. Lack of nutritional knowledge among Norwegian medical students concerning vegetarian diets. J. Public Health 2020, 7. [CrossRef]

307. Bettinelli, M.E.; Bezze, E.; Morasca, L.; Plevani, L.; Sorrentino, G.; Morniroli, D.; Giannì, M.L.; Mosca, F. Knowledge of health professionals regarding vegetarian diets from pregnancy to adolescence: An observational study. Nutrients 2019, 11, 1149. [CrossRef] [PubMed]

308. Hamiel, U.; Landau, N.; Eshel Fuhrer, A.; Shalem, T.; Goldman, M. The Knowledge and Attitudes of Pediatricians in Israel Towards Vegetarianism. J. Pediatr. Gastroenterol. Nutr. 2020, 71, 119-124. [CrossRef]

309. Ha, B. The Power of Plants: Is a Whole-Foods, Plant-Based Diet the Answer to Health, Health Care, and Physician Wellness? Perm. J. 2019, 23. [CrossRef]

310. Nestle, M.; Baron, R.B. Nutrition in medical education: From counting hours to measuring competence. JAMA Intern. Med. 2014, 174, 843-844. [CrossRef]

311. Mulpuri, L.; Allen, N.; Lunde, A.; Thomas, S.; Ray, M.; Polanco, E.; Cret, N.; Molinari, J.; Dowell, L. Rooting for Wellness: An Initiative Introducing Plant-Based Nutrition to First Year Medical Students. Int. J. Dis. Reversal Prev. 2021, 3, 12. [CrossRef]

312. Saldivar, B.; Al-Turk, B.; Brown, M.; Aggarwal, M. Successful Incorporation of a Plant-Based Menu Into a Large Academic Hospital. Am. J. Lifestyle Med. 2021, 7. [CrossRef]

313. Aggarwal, M.; Grady, A.; Desai, D.; Hartog, K.; Correa, L.; Ostfeld, R.J.; Freeman, A.M.; McMacken, M.; Gianos, E.; Reddy, K.; et al. Successful Implementation of Healthful Nutrition Initiatives into Hospitals. Am. J. Med. 2020, 133, 19-25. [CrossRef]

314. Aggarwal, M.; Singh Ospina, N.; Kazory, A.; Joseph, I.; Zaidi, Z.; Ataya, A.; Agito, M.; Bubb, M.; Hahn, P.; Sattari, M. The Mismatch of Nutrition and Lifestyle Beliefs and Actions Among Physicians: A Wake-Up Call. Am. J. Lifestyle Med. 2020, 14, 304-315. [CrossRef]

315. Storz, M. Barriers to the Plant-Based Movement: A Physician's Perspective. Int. J. Dis. Reversal Prev. 2020, 2, 4. [CrossRef]

316. Storz, M.A. Is There a Lack of Support for Whole-Food, Plant-Based Diets in the Medical Community? Perm. J. 2018, 23, 18-068. [CrossRef]

317. U.S. National Library of Medicine. National Library of Medicine; US National Institutes of Health: Bethesda, MD, USA, 2021. Available online: ClinicalTrials.gov (accessed on 1 December 2021).

318. Medawar, E.; Huhn, S.; Villringer, A.; Veronica Witte, A. The effects of plant-based diets on the body and the brain: A systematic review. Transl. Psychiatry 2019, 9, 226. [CrossRef] [PubMed]

319. Katcher, H.I.; Ferdowsian, H.R.; Hoover, V.J.; Cohen, J.L.; Barnard, N.D. A worksite vegan nutrition program is well-accepted and improves health-related quality of life and work productivity. Ann. Nutr. Metab. 2010, 56, 245-252. [CrossRef]

320. Spar SPAR Online Grocery Shop, Spar Slovenija Trgovsko Podjetje d. o. o., Ljubljana, Slovenia. 2021. Available online: https: / / www.sparindia.com/ (accessed on 1 December 2021).

321. Mercator Mercator Online Grocery Shop, Družba Poslovni Sistem Mercator, d. d., Ljubljana, Slovenia. 2021. Available online: https:/ / www.mercatorgroup.si/en/home-en-us/ (accessed on 1 December 2021).

322. MÜLLER MÜLLER Online Grocery Shop, Müeller Drogerija d. o. o., Ljubljana, Slovenia. 2021. Available online: https: //www.mueller.si/letaki-in-revije/ (accessed on 1 December 2021).

323. Hofer HOFER Online Grocery Shop, Hofer Trgovina d. o. o., Ljubljana, Slovenia. 2021. Available online: https://www.hofer.at/ de/onlineshop/onlineshop-aktionsartikel.html (accessed on 1 December 2021).

324. Hiti Dvoršak, A.; Bele, S. Stopnja Samooskrbe s Hrano; Slovenian Environment Agency-ARSO: Ljubljana, Slovenia, 2020.

325. Bredač, M.; Bele, S.; Brečko, J.; Hiti, A.; Kožar, M.; Moljk, B.; Travnikar, T.; Zagorc, B. Poročilo o Stanju Kmetijstva, živilstva, Gozdarstva in Ribištva; Agricultural Institute of Slovenia: Ljubljana, Slovenia, 2020.

326. Slavich, G.M. Life Stress and Health: A Review of Conceptual Issues and Recent Findings. Teach. Psychol. 2016, 43, 346-355. [CrossRef] [PubMed]

327. Karlsen, M.C.; Pollard, K.J. Strategies for practitioners to support patients in plant-based eating. J. Geriatr. Cardiol. 2017, 14, 338-341. [PubMed] 
328. Reipurth, M.F.S.; Hørby, L.; Gregersen, C.G.; Bonke, A.; Perez Cueto, F.J.A. Barriers and facilitators towards adopting a more plant-based diet in a sample of Danish consumers. Food Qual. Prefer. 2019, 73, 288-292. [CrossRef]

329. Fresán, U.; Rippin, H. Nutritional Quality of Plant-Based Cheese Available in Spanish Supermarkets: How Do They Compare to Dairy Cheese? Nutrients 2021, 13, 3291. [CrossRef]

330. Alcorta, A.; Porta, A.; Tárrega, A.; Alvarez, M.D.; Pilar Vaquero, M. Foods for Plant-Based Diets: Challenges and Innovations. Foods 2021, 10, 293. [CrossRef]

331. Crimarco, A.; Springfield, S.; Petlura, C.; Streaty, T.; Cunanan, K.; Lee, J.; Fielding-Singh, P.; Carter, M.M.; Topf, M.A.; Wastyk, H.C.; et al. A randomized crossover trial on the effect of plant-based compared with animal-based meat on trimethylamine-N-oxide and cardiovascular disease risk factors in generally healthy adults: Study with Appetizing PlantfoodMeat Eating Alternative Trial (SWAP-MEAT). Am. J. Clin. Nutr. 2020, 112, 1188-1199. 